\title{
Assessment of mercury speciation in feathers using species-specific isotope dilution
}

analysis

Marina Renedo $^{1,2^{*}}$, Paco Bustamante ${ }^{1}$, Emmanuel Tessier ${ }^{2}$, Zoyne Pedrero ${ }^{2}$, Yves Cherel ${ }^{3}$, David Amouroux ${ }^{2 *}$

${ }^{1}$ Littoral Environnement et Sociétés (LIENSs), UMR 7266 CNRS-Université de la Rochelle, 2 rue Olympe de Gouges, 17000 La Rochelle, France

${ }^{2}$ Institut des sciences analytiques et de physico-chimie pour l'environnement et les matériaux, CNRS-UPPA-UMR-5254, Hélioparc, 2 Avenue du Président Pierre Angot, Pau, 64053, France

${ }^{3}$ Centre d'Etudes Biologiques de Chizé (CEBC), UMR 7372 CNRS-Université de La Rochelle, 79360 Villiers-en-Bois, France

*Corresponding authors: marina.renedoelizalde@univ-pau.fr; david.amouroux @univ-pau.fr 


\begin{abstract}
:
Seabirds are considered as effective sentinels of environmental marine contamination and their feathers are extensively used as non-lethal samples for contaminant biomonitoring. This tissue represents the main route for mercury $(\mathrm{Hg})$ elimination in seabirds and contains predominantly methylmercury $(\mathrm{MeHg})$. In this work, we developed a robust analytical technique for precise and accurate simultaneous quantification of $\mathrm{MeHg}$, inorganic $\mathrm{Hg}(\mathrm{iHg})$ and consequently total $\mathrm{Hg}$ (THg), in feathers by gas-chromatography (GC)-ICPMS analyses using species-specific isotope dilution technique. An optimisation of the extraction method was carried out by testing different extraction systems, reagents and spiking procedures using an internal reference feather sample. The procedure was validated for $\mathrm{MeHg}$ and $\mathrm{THg}$ concentrations with a human hair certified reference material. Microwave nitric acid extraction with spike addition before the extraction provided the best recovery and was chosen as the most appropriate species simultaneous extraction method (SSE). An additional assessment was performed by comparison of our developed extraction method and a MeHg specific extraction technique (MSE) classically used for $\mathrm{Hg}$ speciation studies on feathers. The developed method was applied to feather samples from a large number of seabirds from the Southern Ocean (penguins, albatrosses, petrels and skuas) to investigate the variability of $\mathrm{Hg}$ speciation across a large range of $\mathrm{Hg}$ exposure conditions and concentrations. In all cases, $\mathrm{MeHg}$ accounted for $>90 \%$ of $\mathrm{THg}$, thus verifying the predominance of organic $\mathrm{Hg}$ over $\mathrm{iHg}$ in feathers.
\end{abstract}

Keywords: seabirds, Southern Ocean, GC-ICPMS, methylmercury, inorganic mercury, interspecies transformations, keratin 


\section{Introduction}

Mercury (Hg) is a globally distributed pollutant of major concern for humans and wildlife, whose toxicity is known to be dependent on its molecular speciation. Methylmercury (MeHg) is considered the most toxic $\mathrm{Hg}$ species and, once acquired by dietary uptake, it accumulates in organisms and biomagnifies within the food webs [1,2]. In aquatic systems, anaerobic microorganisms such as sulphate and iron reducing bacteria (SRB and IRB) transform inorganic $\mathrm{Hg}(\mathrm{iHg})$ in $\mathrm{MeHg}$ [3-5], resulting in its incorporation into the food chain. Hence top predators, particularly those linked to aquatic ecosystems, are at highest risk for increased dietary $\mathrm{Hg}$ exposure, especially $\mathrm{MeHg}$, leading to potential $\mathrm{Hg}$-related health effects [6] and to consequences at the population level [7].

Birds have been extensively used as effective bioindicators of $\mathrm{Hg}$ contamination in the environment, particularly of marine ecosystems [8]. Due to their high position on the aquatic food webs and their long life span, seabirds accumulate significant levels of $\mathrm{Hg}$ in their tissues. Feathers are interesting samples to analyse because they represent the main route of $\mathrm{Hg}$ elimination in seabirds, so contain most of their Hg body burden [9-12]. Moreover, feathers can be easily and non-destructively sampled on live individuals. During moult, most of the $\mathrm{Hg}$ stored within internal tissues (70-90\%) is remobilised into growing feathers [11], where it is sequestered in the sulphydryl groups of the keratin molecules and cannot be reincorporated into internal tissues. Once bound to keratin, $\mathrm{Hg}$ is physically and chemically stable [13] and resistant to a variety of rigorous treatments [14]. Although other metals such as lead or cadmium are supposed to be incorporated in feathers by atmospheric input, the homogenous distribution pattern of $\mathrm{Hg}$ previously observed in feathers has led to hypothesize that $\mathrm{Hg}$ contamination is more likely due to endogenous causes (food and physiology) and is not affected by atmospheric exposure [15]. Nevertheless, gaseous $\mathrm{Hg}$ adsorption has been recently demonstrated in human hair under $\mathrm{Hg}$ vapour exposure [16,17], suggesting the possibility of direct $\mathrm{Hg}$ deposition also in feathers under high gaseous $\mathrm{Hg}$ ambient concentrations which could potentially have a repercussion on the use of bird feathers from museum collections for retrospective investigation 
on $\mathrm{Hg}$ temporal trends. However, this process is unlikely to occur in feathers of seabirds inhabiting non-contaminated areas. The first research study of $\mathrm{Hg}$ speciation in feathers was carried out by Thompson and Furness [18] in various seabird species, in which they found that $\mathrm{Hg}$ incorporated into this tissue was mainly composed of MeHg (77-118\%). A dominance of $\mathrm{MeHg}$ in feathers was also observed in following studies [19-21]. Hg has been therefore assumed to be present almost exclusively under its organic form in feathers while no accurate determination of $\mathrm{iHg}$ has been achieved so far. Total $\mathrm{Hg}$ concentrations $(\mathrm{THg}$ ) are often measured for $\mathrm{MeHg}$ quantification in feathers as an economical alternative to speciation analyses. Actually, direct analyses of $\mathrm{MeHg}$ in feathers are usually considered on studies focused on temporal variations on $\mathrm{Hg}$ concentrations using historical feather collections from museums, e.g [22-25]; where a potential contamination of iHg has been found to be produced by the successive application of preservatives containing $\mathrm{HgCl}_{2}$ and methyl-bromide [26]. Analyses of $\mathrm{Hg}$ speciation in feathers are therefore essential to better evaluate $\mathrm{Hg}$ exposure and metabolic processes in birds.

Different analytical methods for $\mathrm{Hg}$ speciation in feather samples have been reported in previous studies. Thompson and Furness [27] proposed the first method to determine concentrations of $\mathrm{THg}$ and $\mathrm{MeHg}$ in feathers by $\mathrm{MeHg}$ selective extraction (adapted from Uthe et al. [28]) for subsequent analyses by cold-vapour atomic fluorescence spectroscopy (CVAFS). This procedure has been widely used by studies of $\mathrm{Hg}$ speciation in feathers [19,20,22,29-31]. More developed analytical techniques were later performed by using gas chromatography in order to separate $\mathrm{Hg}$ species: gas chromatography coupled to atomic fluorescence spectroscopy (GC-AFS) [32,33]; gas chromatography coupled to electron-capture detector (GC-ECD) [34], and single isotope dilution analysis by gas chromatography coupled to ICP-MS (S-IDA-GC-ICPMS) with single isotope spike (only isotopically labelled $\mathrm{MeHg}$ was added) [26]. However, these analytical techniques do not allow correcting possible losses or transformations between $\mathrm{Hg}$ species and provide uniquely the quantification of $\mathrm{MeHg}$ and $\mathrm{THg}$ concentrations, so the determination of $\mathrm{iHg}$ concentrations needs to be calculated as the 
difference between both compounds' concentrations. A synthesis of the results published in previous studies have been compiled in Table 1. It can be observed that in some cases $\mathrm{MeHg}$ proportion values of feathers exceed $100 \%$ of $\mathrm{THg}$, indicating a lack of accuracy or precision in MeHg quantification by classical techniques. This observation enhances the interest of our developed method for accurate and precise $\mathrm{Hg}$ species analyses.

The quantification of both $\mathrm{Hg}$ species involves an analytical challenge due to potential losses or species transformation reactions (i.e., $\mathrm{MeHg}$ demethylation or $\mathrm{iHg}$ methylation processes) which could occur during the whole analytical procedure, leading to erroneous results in the quantification of $\mathrm{Hg}$ species concentrations [35]. GC-ICPMS using a double isotopic dilution method provides the simultaneous measurement of both $\mathrm{MeHg}$ and $\mathrm{iHg}$, and subsequently $\mathrm{THg}$ as $\mathrm{THg}=\mathrm{MeHg}+\mathrm{iHg}$, with high precision [36,37]. Obtained data can also be processed by Isotope Pattern Deconvolution (IPD), a general model for isotope dilution that takes into consideration both spikes (isotopically enriched solutions) and natural species, and enables the determination of potential interconversion reactions and the consequent correction of $\mathrm{Hg}$ species concentrations [35]. Accordingly, isotope dilution methods guarantee a better precision and accuracy than conventional quantification by external calibration [37]. Previous studies published method developments (extraction and derivatisation) for $\mathrm{Hg}$ speciation by IDGC-ICPMS in biological samples, such as seafood [37] or human hair [38]. Preliminary work was carried out on human hair thus allowing an initial approach of $\mathrm{Hg}$ species analyses on keratin samples by evaluating different extraction methods [38].

Our research work includes the assessment of two keratin-based materials (feathers and hair) and considers further analytical strategies, such as the isotopically enriched spiking technique in all the extraction methods tested or the additional evaluation of classic $\mathrm{MeHg}$ selective extraction. This study evaluates in depth analytical performances on keratin samples and provides information about non-desirable reactions occurring during both extraction and derivatisation of each analytical procedure tested. $\mathrm{Hg}$ speciation in feathers of a great number of 
seabirds from the Southern Ocean have been successfully determined by applying the developed method.

\section{Experimental}

\subsection{Feather samples and reference materials}

Due to the non-existence of commercialised feather reference material, we prepared a pool sample of feathers collected from different individuals of king penguin (Aptenodytes patagonicus) from Crozet Islands which was used as internal reference standard (IRM) for our laboratory feather analyses and named P-KP. For the validation of the results, all the analyses were performed on a human hair certified reference material (NIES-13). Human hair has been chosen as the most appropriate matrix for validation of feather analysis since they have a similar composition, almost completely composed of keratin. NIES-13 presents high Hg concentrations and contains $\sim 90 \%$ of $\mathrm{MeHg}\left([\mathrm{THg}]=4420 \pm 200 \mathrm{ng} \cdot \mathrm{g}^{-1}\right.$ and $[\mathrm{MeHg}]=3800 \pm 400 \mathrm{ng} \cdot \mathrm{g}^{-1}$, certified values).

The evaluation of MSE and SSE methods was accomplished with feather samples of two marine bird species: the white-chinned petrel (Procellaria aequinoctialis) and Antarctic prion (Pachyptila desolata). A pool of feathers from a raised pheasant (Phasianus colchicus) was used as a control since terrestrial birds are known to accumulate lower amounts of $\mathrm{Hg}$ in their tissues than aquatic birds [8].

The developed SSE method was applied to feathers from several seabird species exhibiting a large range of $\mathrm{Hg}$ concentrations. The selection of marine birds comprises seven species of penguins: emperor (Aptenodytes forsteri), king (A. patagonicus), Adélie (Pygoscelis adeliae), gentoo (P. papua), macaroni (Eudyptes chrysolophus), southern rockhopper (E. chrysocome filholi) and northern rockhopper (E. chrysocome moseleyi) penguins, and the wandering albatross (Diomedea exulans), northern (Macronectes halli) and southern (M. giganteus) giant petrels, Antarctic prion (Pachyptila desolata) and Antarctic (Catharacta maccormicki) and subantarctic (C. lönnbergi) skuas. Feather sampling was conducted in four sites of the French 
Southern and Antarctic Territories: Adélie Land (66 $\left.40^{\circ} \mathrm{S}, 140^{\circ} 10^{\prime} \mathrm{E}\right)$, Crozet Islands (46 $26^{\circ} \mathrm{S}$, $\left.51^{\circ} 45^{\prime} \mathrm{E}\right)$, Kerguelen Islands $\left(49^{\circ} 21^{\prime} \mathrm{S}, 70^{\circ} 18^{\prime} \mathrm{E}\right)$ and Amsterdam Island (37 $\left.50^{\prime} \mathrm{S}, 7^{\circ} 31^{\prime} \mathrm{E}\right)$. Feather sampling dates of each seabird species are indicated in Table 4.

\subsection{Sample preparation and extraction procedures}

Feathers were cleaned in a 2:1 chloroform:methanol solution for $5 \mathrm{~min}$ in an ultrasonic bath, followed by two methanol rinses to remove surface impurities, and then oven dried at $50^{\circ} \mathrm{C}$ during $48 \mathrm{~h}$ [39]. They were afterwards well homogenised in order to acquire accurate analytical results avoiding within-feather variation in $\mathrm{Hg}$ sequestration, which could produce fluctuations in observed $\mathrm{Hg}$ measurement [15]. Feathers were finely cut with scissors to obtain a homogenous sample. In the particular case of king penguin (P-KP), white-chinned petrel and Antarctic prion (used for the extraction method assessment since more quantity of sample was available), feathers were cut with scissors and additionally grinded in a planetary ball mill (Retsch PM400) at $400 \mathrm{rpm}$. We noted that during homogenization with planetary ball mill, a potential contamination of $\mathrm{iHg}$ could occur and therefore, this homogenisation method was later discarded.

Different reagents were tested for the optimisation of the extraction method: acid digestion using nitric acid $\left(\mathrm{HNO}_{3} \cdot 6 \mathrm{~N}\right.$, INSTRA quality) and alkaline digestion by tetramethylammonium hydroxide (25\% TMAH in $\mathrm{H}_{2} \mathrm{O}$, Sigma Aldrich). Sample amounts between $0.20-0.25 \mathrm{~g}$ were digested in $5 \mathrm{~mL}$ of reagent. Two different extraction systems were also tested: microwave (MW) and Hotblock (HB) (Figure 1). Microwave-assisted extraction was performed using a CEM microwave system (Discover SP-D, CEM Corporation) coupled to an autosampler Explorer 487296 (USA). The extraction was carried out in CEM Pyrex vessels by 1 min of warming up to $75^{\circ} \mathrm{C}$ and $3 \mathrm{~min}$ at $75^{\circ} \mathrm{C}$ with magnetic agitation to homogenise the samples. $\mathrm{HB}$ extractions were performed in closed PFA vessels (Savillex) of $50 \mathrm{~mL}$ at $85^{\circ} \mathrm{C}$ during 2 hours in a SC100-36 Hotblock (Environmental Express, South Carolina, USA). The addition of isotopic enriched standard solutions was tested before and after the extraction process. In the case of spike addition before extraction, standard solutions were added directly 
to the solid sample whereas for spike addition after extraction solutions were added to the extract. All samples were extracted in triplicate.

Prior to $\mathrm{Hg}$ species analyses, samples were derivatized at $\mathrm{pH} 4$ by ethylation using sodium tetraethylborate $\left(\mathrm{NaBEt}_{4}, 5 \%\right)$, in order to produce volatile ethylated forms of $\mathrm{Hg}$ that could be separated by gas chromatography, and then extracted in isooctane by mechanical shaking using an orbital shaker during $20 \mathrm{~min}$. Hg species analyses were carried out by GC-ICPMS Trace Ultra GC equipped with a Triplus RSH autosampler coupled to an ICP-MS XSeries II (Thermo Scientific, USA) as detailed in previous works [35].

\subsection{Total Hg analyses}

Total $\mathrm{Hg}$ concentrations were quantified by using an advanced $\mathrm{Hg}$ analyser spectrophotometer (AMA-254, Altec). Homogenised samples (aliquots between 10 and $15 \mathrm{mg}$ ) were analysed after thermal destruction and gold amalgamation (drying time $60 \mathrm{~s}$, decomposition time $180 \mathrm{~s}$, waiting time for quantitative trapping of released mercury on the gold amalgamator $45 \mathrm{~s}$ ). A matrix dependent calibration was performed with human hair reference material (NIES-13) by addition of different masses of sample, following EPA method 7473 [40]. This calibration was validated by quantification of a second human hair reference material (IAEA-086), providing an accuracy of $92 \pm 5 \%(n=5)$ relative to recommended reference value. Feather THg concentrations were calculated by this calibration in order to correct matrix effects associated to keratinised samples. Several blanks were analysed at the beginning of each analytical session. Limit of detection (LOD), calculated for blank average values (15 blanks) plus three times the standard deviation (SD) of these blanks (IUPAC), was $0.15 \mathrm{ng} \mathrm{g}^{-1}$.

\subsection{Quantification methods for isotopic dilution calibration}

$\mathrm{Hg}$ species concentrations were determined by different quantification approaches in order to deeply assess analytical performances on keratin samples. Two quantification methods for isotope dilution technique were used: single-IDA and IPD. The concentrations were calculated by both methods and the transformation factors were calculated using IPD, allowing to evaluate interconversion reactions ( $\mathrm{M} \%$ and $\mathrm{D} \%$ ) that occur during both extraction and derivatisation of 
each analytical procedure tested. For double isotope dilution technique, the sample is spiked with known amounts of two isotope tracers (in this case ${ }^{199} \mathrm{iHg}$ and ${ }^{201} \mathrm{MeHg}$ ) to alter the natural isotopic abundance of the studied endogenous species $\left({ }^{202} \mathrm{iHg}\right.$ and $\left.{ }^{202} \mathrm{MeHg}\right)$. Quantification is then based on the measurement of the mixed isotope ratios, as explained elsewhere [36,37]. Single-IDA model consists on the specific measurement of $\mathrm{Hg}$ species separately. Only two isotopes are considered for the quantification of each $\mathrm{Hg}$ species $\left(\mathrm{R}^{202 / 201}\right.$ for $\mathrm{MeHg}$ and $\mathrm{R}^{202 / 199}$ for $\mathrm{iHg}$ ). IPD takes into account all the different isotopic patterns of both spikes and endogenous species, providing the determination of possible inter-species transformations (M\% and $\mathrm{D} \%$ ) and the consequent correction of concentrations [37]. The reported results of [THg] were calculated as the sum of $[\mathrm{MeHg}]$ and $[\mathrm{iHg}]$ determined by ID-GC-ICPMS, and were compared to $[\mathrm{THg}]$ determined by AMA-254 in order to evaluate their similarity and verify the recovery of the extraction.

\subsection{Adaptation of MeHg selective extraction method (MSE)}

A specific extraction technique of $\mathrm{MeHg}$ was applied in feather samples for the analysis of Hg speciation by ID-GC-ICPMS. The method, adapted from Uthe et al. [28], consists in a first extraction of $\mathrm{MeHg}$ in an organic phase (toluene) followed by a reverse extraction in aqueous phase. P-KP and feather samples from different marine bird species (Antarctic prion and whitechinned petrel) and one terrestrial species (pheasant) were used to assess the selectivity of this method, as they exhibit a wide range of $\mathrm{Hg}$ concentrations and different $\mathrm{Hg}$ species distribution. NIES-13 was also extracted in triplicate and analysed.

Firstly, 0.15-0.20 g of feather samples were extracted by alkaline extraction in a HB system in Savillex vessels with sodium hydroxyde ( $\mathrm{NaOH}$ [reagent grade], 10M, $4 \mathrm{~mL})$ during $2 \mathrm{~h}$ at $60^{\circ} \mathrm{C}$, following Thompson et al. [27]. Then, $0.5 \mathrm{~mL}$ of extract was diluted with $4.5 \mathrm{~mL}$ of milliQ water in $50 \mathrm{~mL}$ tubes and neutralized afterwards with $0.1 \mathrm{~mL}$ of sulfuric acid $\left(\mathrm{H}_{2} \mathrm{SO}_{4}\right.$, ACS Grade 95-98\%). $5 \mathrm{~mL}$ acidic $\mathrm{NaBr}\left(30 \%\right.$ w/w NaBr [Ultragrade, 99.5\%] in $\mathrm{H}_{2} \mathrm{SO}_{4} 4 \mathrm{M}$ ), $10 \mathrm{~mL}$ of aqueous $\mathrm{CuSO}_{4}(2.5 \%$ w/w [reagent grade, $99 \%$ ]) and $10 \mathrm{~mL}$ of toluene (anhydrous, 99.8\%) were added to the extracts. Samples were agitated at $420 \mathrm{rpm}$ for 1 hour in an orbital 
shaking table. Secondly, an amount of $4 \mathrm{~mL}$ of toluene (MeHg passes into the organic phase) was transferred in a Falcon tube with $4 \mathrm{~mL}$ of sodium thiosulphate $\left(\mathrm{Na}_{2} \mathrm{~S}_{2} \mathrm{O}_{3}, 0.005 \mathrm{M}\right.$ [ACS grade, 98\%]). Samples were vortexed during $1 \mathrm{~min}$. An aliquot of sodium thiosulphate (MeHgthiosulphate) was collected in $5 \mathrm{~mL}$ tubes and kept at $4^{\circ} \mathrm{C}$ until analyses. The addition of isotopically enriched solutions $\left({ }^{201} \mathrm{MeHg}\right.$ and $\left.{ }^{199} \mathrm{iHg}\right)$ was tested in two different steps: 1$)$ before $\mathrm{NaOH}$ extraction and 2) before specific $\mathrm{MeHg}$ extraction (after $\mathrm{NaOH}$ extraction) (Figure 2). Prior to derivatisation, the addition of a solution of $\mathrm{HCl}$ to the $\mathrm{MeHg}$-thiosulphate extract is required to reduce competition with sulphur groups during derivatisation, then different concentrations of $\mathrm{HCl}$ solution were tested. The concentrations of the $\mathrm{NaBEt}_{4}$ solution for ethylation were as well optimised. These tests were performed and validated for NIES-13. The best results were achieved when adding $2 \mathrm{~mL}$ of $\mathrm{HCl}$ solution $(5 \% \mathrm{v} / \mathrm{v})$ and $200 \mu \mathrm{L}$ of $\mathrm{NaBEt}_{4}$ (5\% v/v) to $200 \mu \mathrm{L}$ of thiosulphate extract. The limit volume of thiosulphate extract for derivatisation is $500 \mu \mathrm{L}$, since a higher volume involved matrix effects.

\subsection{Statistical tests for environmental feather samples}

Statistical analyses were performed using XLSTAT 2016. Normality and homoscedasticity were firstly checked for the whole dataset by using Shapiro-Wilk and Breusch-Pagan tests, respectively. Since not all the results all the samples presented a normal distribution and homoscedasticity, non-parametric test was used (Kruskal-Wallis coupled to Conover-Iman procedure with Bonferroni correction). The significance level was fixed of $\alpha=0.05$ for all tests. Values are means $\pm \mathrm{SD}$.

\section{Results and discussion}

\subsection{Comparison of speciation extraction procedures: optimisation}

Results of $[\mathrm{MeHg}]$, $[\mathrm{iHg}]$ and $[\mathrm{THg}]($ as $[\mathrm{MeHg}]+[\mathrm{iHg}])$ determined by - single-IDA and IPD and transformation factors (M\% and D\%) calculated by IPD for each selected extraction procedure are presented for both reference materials NIES-13 (Table 2) and P-KP (Table 3). 
All the extraction methods tested provided satisfactory results for $\mathrm{Hg}$ concentrations for the two reference materials, except acid extractions with spike addition after extraction, which resulted in an insufficient recovery for both Hg species. In the case of NIES-13, recoveries for MW acid extractions with spike addition after extraction were $80.6 \pm 1 \%$ and $76.5 \pm 4.6 \%$ for $\mathrm{MeHg}$ and $\mathrm{THg}$, respectively, while recoveries of $96.0 \pm 1.2 \%$ and $95.9 \pm 0.2 \%$ were achieved for spike addition before extraction. For P-KP, differences between both spiking procedures were not as remarkable as for NIES-13, but better results of THg were obtained when spike addition was added before $\left([\mathrm{THg}]=3899 \pm 62 \mathrm{ng} \cdot \mathrm{g}^{-1}\right)$ than after MW acid extraction $([\mathrm{THg}]=3249 \pm 118$ $\left.\mathrm{ng} \cdot \mathrm{g}^{-1}\right)$. This result indicates that spike addition before extraction is highly recommended for hair and feather samples for correcting possible losses and/or species interconversion processes occurring also during the acid extraction step.

TMAH extracts exhibited lower sensitivity for both keratinised matrixes, which consequently induced a higher standard deviation (SD) in determination and a source of error in quantification, even if no substantial alteration of the obtained isotopic ratio was observed. This response demonstrates the occurrence of undesirable competing reactions during derivatisation when using TMAH as extraction reagent. In an acid medium, $\mathrm{MeHg}$ from the spike solution is less complexed with the thiol ligands of keratin. Thus, $\mathrm{MeHg}$ is more available for ethylation so the derivatization step will be more effective. In the opposite case, in an alkaline medium there is a stabilization of the $\mathrm{MeHg}$ by the complexes formed with the thiols, a minor degradation exists but, at the same time, MeHg will be less reactive and there could be interferences by other derivatized molecules (competition) [41]. Thus, when extracting keratinised samples in alkaline medium the risk of error by integration of attenuated peaks must be taken into account.

Generally, no significant differences in concentration values were observed between Dsingle-IDA and IPD quantification methods for our two reference materials. The only exception was found in the case of NIES-13 MW TMAH with spike addition before extraction. The correction of a substantial D\% factor by IPD (26.6 $\pm 1.0 \%)$ involved a significant difference on iHg concentrations calculated by single-IDA $\left(1463 \pm 398 \mathrm{ng} \cdot \mathrm{g}^{-1}\right)$ and IPD $\left(574 \pm 68 \mathrm{ng} \cdot \mathrm{g}^{-1}\right)$. 
This phenomenon also occurred under the same extraction conditions for P-KP, which exhibited a $\mathrm{D} \%$ of $11.3 \pm 10.4 \%$. According to the results obtained for the rest of extraction methods when spiked solutions were added before extraction, lower but also important $\mathrm{D} \%$ factors was obtained: MW acid (5.5 $\pm 1.0 \%$ and $4.5 \pm 0.2 \%)$, HB acid $(8.4 \pm 0.1 \%$ and $3.3 \pm 0.8 \%)$ and $\mathrm{HB}$ alkaline $(7.7 \pm 0.3 \%$ and $6.5 \pm 1.5 \%)$ for NIES-13 and P-KP samples, respectively. Indeed, for the same extraction conditions but spike addition after extraction, no significant $\mathrm{D} \%$ were observed on hair and feathers. This result means that significant demethylation reactions mainly occurred during extraction, particularly in the case of MW extraction with TMAH. This could be explained by an influence of different behaviour or transformation rates between endogenous $\mathrm{Hg}$ and isotopically enriched $\mathrm{Hg}$ from spike solutions [42]. Differences of complexation and lability patterns between $\mathrm{Hg}$ from matrix and enriched $\mathrm{Hg}$ potentially occur during the extraction procedure, affecting the accuracy of $\mathrm{Hg}$ analysis by species-specific isotope dilution. In the previous assessment on human hair samples [38], demethylation during extraction was uniquely observed for $\mathrm{HNO}_{3}$ oven extraction at $80{ }^{\circ} \mathrm{C}(4.6 \pm 2.5 \%)$. Contrary to our results, no demethylation reactions occurred during TMAH extraction.

Concerning the results obtained for procedures with spike addition after extraction, a significant $\mathrm{M} \%$ was observed for alkaline extractions of P-KP by both systems: MW $(8.8 \pm 1.9 \%)$ and HB (11.9 $\pm 8.6 \%)$. Much lower M\% factors were obtained in the case of hair TMAH extracts by MW $(3.0 \pm 1.5 \%)$ and HB $(1.3 \pm 1.0 \%)$. Therefore, important methylation reactions occurred in feather TMAH extracts when spike was added after but not when it was added before. It should also be considered that an additional source of error could exist in quantification of TMAH extraction due to low-sensitivity. No significant D\% was obtained for extractions with spike addition after extraction, which means that demethylation artefacts barely occurred during derivatisation step whatever the reagent used. Laffont et al. [38] did not observe methylation but considerable demethylation $(4.2 \pm 0.8 \%)$ during derivatisation of hair TMAH extracts. Notable demethylation reactions occurred during extraction whatever the reagent and extraction system used, and particularly when using TMAH. Due to the existence of important 
inter-species conversion reactions during extraction and derivatization of keratin-based material samples, the addition of the enriched solutions before acid or alkaline extraction is highly recommended independently of the method used.

\subsection{Comparison of analytical performances}

Since no significant differences were observed between MW and HB extraction systems, MW was chosen as the most suitable extraction system since it provides a better-quality control of the extraction, permitting a homogenisation of the sample by electromagnetic stirring and automatic and individually controlled temperature and pressure conditions. Results of MW extraction with spike addition before extraction were evaluated in order to choose the most appropriate reagent (Table S1). The sensitivity was assessed by the measurement of calibration slopes calculated as the relation of the peak area obtained for ${ }^{202} \mathrm{MeHg}$ (counts per second, cps) divided by the concentration of $\mathrm{MeHg}$ injected $\left(\mathrm{ng} \cdot \mathrm{L}^{-1}\right)$ for the injection in $2 \mu \mathrm{L}$ of isooctane. Much higher sensitivity was obtained for $\mathrm{HNO}_{3}$ than for TMAH extracts obtained for both hair and feathers. Better precision (RSD) was achieved by $\mathrm{HNO}_{3}$ extraction than by TMAH for the two reference samples. Such important difference is also a consequence of lower sensitivity achieved after alkaline extraction. Accuracy was calculated by recoveries of $\mathrm{MeHg}$ and $\mathrm{THg}$ relative to NIES-13 certified values. Although the most satisfactory recoveries (for both $\mathrm{MeHg}$ and THg of NIES-13) were obtained for TMAH MW extraction with spike addition before the extraction by IPD quantification, this kind of extraction was refused as an pertinent method due to the low sensitivity obtained when using TMAH reagent. Nitric acid MW extraction with spike addition before extraction provided much higher sensitivity and precision, consequently it was chosen for simultaneous species extraction (SSE) on hair and feather samples. For this selected SSE method, mean recoveries for MeHg and THg in NIES-13 quantified by single-IDA $(96.0 \pm 1.2 \%$ and $95.9 \pm 0.2)$ and IPD $(94.2 \pm 1.4 \%$ and $93.7 \pm 2.3 \%)$ were satisfactory and very similar, suggesting the possibility of using both quantification approaches as valid analytical solutions. Due to practical reasons, single-IDA was chosen in this study to avoid the long data treatment required by IPD. Nevertheless, IPD permits the calculation of conversion reactions 
among $\mathrm{Hg}$ species and the consequent correction of concentrations related to these transformations and therefore, it is considered a more powerful approach. Indeed, IPD generally provides more accurate results than a single-IDA except under particular circumstances in which $\mathrm{Hg}$ species concentrations are substantially different within the same sample [43]. In the rest of cases, the level of accuracy of IPD is higher, although it is less precise because the correction of species interconversion is carried out at the expense of the precision of the obtained amount of interconverting analytes [44]. In conclusion, since satisfactory results were obtained either using single-IDA or IPD in hair and feather samples, IPD remains a reference accurate method for metrology and analytical development while single-IDA can be easily used for routine monitoring analyses.

\subsection{Long-term internal reproducibility of SSE method by ID-GC-ICPMS}

An evaluation of long-term internal reproducibility and repeatability of the optimised method was performed on human hair certified reference material (NIES-13) and on our internal reference material for feather samples (P-KP). Extractions by SSE method were performed in triplicate. Internal reproducibility was assessed for triplicate injection of the three extracts of each reference material $(n=9)$, prepared following identical protocols and by the same operator and equipment in each analytical session, with 1-6 months of interval (Figure S1). Since the term reproducibility implies the involvement of measurement by different operators and laboratories, we use the term internal reproducibility. The precision, calculated as the mean RSD, was $1.38 \%$ and $1.49 \%$ for $\mathrm{MeHg}$ and $5.33 \%$ and $1.71 \%$ for $\mathrm{iHg}$ for NIES-13 and P-KP, respectively. Repeatability was estimated by analysing in triplicate the same extract the same day, under identical conditions $(n=3)$. The mean RSD was $1.24 \%$ and $1.64 \%$ for $\mathrm{MeHg}$ and $7.28 \%$ and $3.04 \%$ for $\mathrm{iHg}$ in the case of NIES-13 and P-KP, respectively. A previous analytical publication which developed this method for application to human hair samples [38] obtained a repeatability for triplicate injection of IAEA-86 $(\mathrm{n}=6)$ between $1.0-2.5 \%$ for $\mathrm{MeHg}$ and $0.5-$ $1.8 \%$ for iHg. Accuracy was evaluated using NIES-13 and calculated as the recovery of measured $\mathrm{MeHg}$ and $\mathrm{THg}$ concentrations relative to certified values. $\mathrm{MeHg}$ and $\mathrm{THg}$ mean 
recovery for all the analytical sessions (i.e. average of all the injections), was $94 \pm 2 \%$ and $98 \pm 3 \%$, respectively. Laffont et al. [38] obtained mean recoveries of 98 and $88 \%$ for the reference human hair sample (IAEA-086). Limits of detection (LOD) and quantification (LOQ) were calculated as the sum of spiked $\mathrm{HNO}_{3} \cdot 6 \mathrm{~N}$ blank average values analysed in triplicate (15 blanks of extraction) plus three times the standard deviation (SD) of these blanks for LOD or ten times for LOQ (IUPAC). For extraction of $0.25 \mathrm{~g}$ of hair or feathers in $5 \mathrm{~mL}$ of $\mathrm{HNO}_{3} \cdot 6 \mathrm{~N}$, LOD obtained is $3.24 \mathrm{ng} \mathrm{g}^{-1}$ and $11.62 \mathrm{ng} \mathrm{g}^{-1}$ and LOQ is $9.04 \mathrm{ng} \mathrm{g}^{-1}$ and $30.37 \mathrm{ng} \mathrm{g}^{-1}$, for $\mathrm{MeHg}$ and iHg, respectively.

\subsection{Intercomparison methods for THg concentrations quantification}

Results of THg concentrations were compared for direct quantification by AMA-254 and for the sum of $\mathrm{Hg}$ compounds by speciation analyses (SSE) (Table S2). P-KP feather sample was analysed several times in order to obtain a representative $\mathrm{THg}$ concentration value $\left([\mathrm{THg}]=3816 \pm 275 \mathrm{ng} \cdot \mathrm{g}^{-1}, \mathrm{n}=12\right.$ ). Feather THg concentrations obtained by both methods were satisfactory, with recoveries higher than $97 \%$ when comparing AMA-254 to SSE values. Precision (RSD) was higher by SSE method (0.3-1.6\%) than by AMA-254 (4.3-7.2\%) even if for SSE method analyses are performed for triplicate extraction.

\subsection{Intercomparison between $\mathrm{MeHg}$ selective extraction (MSE) and simultaneous species} extraction (SSE)

Feather samples were extracted by our previously optimised method for $\mathrm{Hg}$ speciation in feathers (SSE) and by MeHg selective extraction (MSE). Results of MeHg concentrations for both methods are given in Table S3. Recoveries of MSE for NIES-13 were calculated relative to $\mathrm{MeHg}$ certified values. For the rest of the samples, recoveries were calculated in function to MeHg concentrations obtained by SSE method. Non-significant differences between the mean concentrations obtained for blank extractions and $\mathrm{iHg}$ fractions quantified by isotope dilution were found for the MSE extracts, meaning that exclusively MeHg was extracted. We observed notable differences between concentrations values for both types of spiking procedures for MSE. In all cases, spike addition before $\mathrm{NaOH}$ extraction provided better results. For NIES-13 
recoveries of $[\mathrm{MeHg}]$ were satisfactory for SSE $(96 \pm 3 \%)$ and MSE with spike addition before

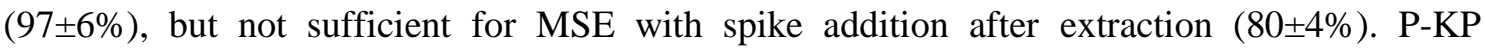
presented recoveries of $[\mathrm{MeHg}]$ of $76 \pm 7 \%$ and $82 \pm 10 \%$ for MSE with spike addition after and before extraction, respectively. Precision (as RSD) was similar for MSE with spike addition after extraction than before extraction. For NIES-13 and P-KP reference samples, extracted in triplicate, precision of MSE with spike after extraction was 4.7\% and 9.0\%; whereas precision obtained for MSE with spike addition before was $6.3 \%$ and $12.3 \%$, respectively. For feather samples, extracted only once, mean RSD was 3.2\% (2.6-4.0\%) and 2.2\% (1.8-4.8\%) for spike addition after and before, respectively. Better results were achieved for MSE with spike addition before $\mathrm{NaOH}$ extraction as it enables the correction of methylation or demethylation reactions occurring during the whole procedure, which in the case of MSE involves several steps that could induce undesirable interconversion reactions.

A logarithmic representation of obtained $[\mathrm{MeHg}]$ values for all the samples tested is shown in Figure 3. Since the addition of spike before $\mathrm{NaOH}$ extraction resulted in better recoveries, only these results of MSE are plotted to compare to SSE. The precision in MeHg quantification appeared to be much higher for SSE method for reference materials (1.26\% for NIES-13 and $1.53 \%$ for P-KP) and feather samples (mean value $1.17 \%(0.27-2.32 \%)$ ). This could mean that MSE is less precise, maybe due to its higher complexity and elevated number of analytical steps. As a general trend, results for both extraction methods agree with the expected values for reference materials and matched for the rest of feathers samples $\left(\mathrm{R}^{2}=0.997\right)$.

MSE can be thus considered as an efficient and valid method to quantitatively extract $\mathrm{MeHg}$ in hair and feather samples covering a great range of $\mathrm{Hg}$ concentrations. However, it is important to highlight that, in this study, MeHg extracted by MSE has been measured by isotope dilution and not by external calibration, allowing to obtain more precise measurements and to correct possible losses or transformations during the whole analytical procedure and providing a more precise quantification of $\mathrm{MeHg}$ concentrations. Determination of $\mathrm{Hg}$ concentrations by external calibration, as it was performed by previously published studies on $\mathrm{Hg}$ speciation using 
MSE [18-20,45], could induce a lack of accuracy and precision and therefore errors in $\mathrm{MeHg}$ quantification.

\section{Hg speciation in feathers from Southern Ocean seabirds}

The optimised SSE method was applied on feather samples from a large number of marine birds from the Southern Ocean (details in section 2.1). This selection of seabird species exploiting different ecological characteristics (such as feeding habits, trophic positions and thus different $\mathrm{Hg}$ exposure conditions) permits to use our developed speciation method in feathers covering a large range of $\mathrm{Hg}$ concentrations (from $375 \pm 87$ to $39924 \pm 29412 \mathrm{ng} \mathrm{THg} \cdot \mathrm{g}^{-1}$, corresponding to Adélie penguins and wandering albatrosses, respectively). Values of $\mathrm{MeHg}$, $\mathrm{iHg}$ and $\mathrm{THg}$ concentrations (as $\mathrm{MeHg}+\mathrm{iHg}$ ) are presented in Table 4. $\mathrm{THg}$ concentrations values obtained by AMA-254 and those calculated as the sum of MeHg and iHg concentrations by SSE method for all the feather samples were highly correlated (Pearson's correlation, $\mathrm{r}=0.985, \mathrm{p}<0.001, \mathrm{n}=175)$ (Figure $\mathrm{S} 2$ ).

Generally, penguins displayed the lowest feather MeHg concentrations whereas southern and northern giant petrels, subantarctic skuas and wandering albatrosses presented significantly higher MeHg concentrations (Kruskal-Wallis, $\mathrm{H}=156.27, \mathrm{p}<0.0001, n=175$ ). Considering the proportion of $\mathrm{MeHg}$ in the feathers, no substantial differences were found among the different analysed species (Kruskal-Wallis, $\mathrm{H}=73.06, \mathrm{p}<0.0001, n=175$ ), with $\mathrm{MeHg}$ being the major $\mathrm{Hg}$ compound for all the individuals. As it was expected, all the feathers displayed more than $80 \%$ of $\mathrm{Hg}$ as MeHg. This result is coherent with a dominant presence of $\mathrm{MeHg}$ in feathers obtained in previous studies on seabirds from different localities [19-21]. It indicates that Hg speciation in feathers is not influenced by the levels of $\mathrm{Hg}$ concentrations, with $\mathrm{MeHg}$ being the most abundant compound since it is preferentially excreted via feathers for detoxification purposes (e.g, [46,47]). Despite the predominance of $\mathrm{MeHg}$ in seabird feathers, the amounts of $\mathrm{iHg}$ appeared to be non-negligible (reaching almost $20 \%$ of total $\mathrm{Hg}$ in some individuals). This result highlights the necessity of measuring both $\mathrm{Hg}$ compounds in feathers to better investigate $\mathrm{Hg}$ exposure and metabolic response of birds. 


\section{Conclusions}

A method for the simultaneous determination of $\mathrm{Hg}$ speciation in feathers was optimised and validated. The evaluation of different extraction procedures, spiking strategies and quantification methods was performed, concluding that nitric acid microwave assisted extraction with spike addition before the extraction was found the most adequate for feathers (and hair) samples. Both single-IDA and IPD quantification methods are proposed as valid analytical approaches for either routine analysis or monitoring issues (single-IDA) or metrology and analytical development purposes (IPD). In our case, due to the high number of feather samples, single-IDA was favoured because it is a more practical option. The developed method demonstrates the capability of the GC-ICPMS by using species-specific isotope dilution for the precise and accurate measurement of $\mathrm{MeHg}$, $\mathrm{iHg}$ and thus $\mathrm{THg}$ as $\mathrm{MeHg}+\mathrm{iHg}$ concentrations and the correction of potential transformations between $\mathrm{MeHg}$ and $\mathrm{iHg}$ compounds during the different analytical steps. It was successfully applied in environmental feather samples where $\mathrm{MeHg}$ appeared to be the major species for all the feathers analysed independently of $\mathrm{THg}$ concentrations. This finding fits well with the evidence that seabirds excrete $\mathrm{MeHg}$ in moulting feathers as a $\mathrm{Hg}$ detoxification strategy. However, non-negligible amounts of $\mathrm{iHg}$ were present in feathers from some individuals. This finding, together with the existence of accidental iHg contamination in feather museum collections, supports the recommended application of methods measuring both $\mathrm{Hg}$ compounds' concentrations in feathers.

Acknowledgments. The authors thank all the fieldworkers that contributed to the collection of seabird feather samples in the frame of the program no. 109 (H. Weimerskirch) supported by the Institut Polaire Français Paul Emile Victor (IPEV) and the Terres Australes et Antarctiques Françaises (TAAF). The present work was supported financially by the Région PoitouCharentes (Nouvelle Aquitaine) through a $\mathrm{PhD}$ grant to $\mathrm{MR}$, and by the the french national programme EC2CO-Biohefect/Ecodyn//Dril/MicrobiEen (TIMOTAAF project). 


\section{References}

[1] R. Bargagli, F. Monaci, D. Cateni, Biomagnification of mercury in an Antarctic marine coastal food web, 169 (1998) 65-76.

[2] R. Bargagli, C. Agnorelli, F. Borghini, F. Monaci, Enhanced deposition and bioaccumulation of mercury in Antarctic terrestrial ecosystems facing a coastal polynya., Environ. Sci. Technol. 39 (2005) 8150-5. doi:10.1021/es0507315.

[3] J.M. Benoit, C.C. Gilmour, A. Heyes, R.P. Mason, C.L. Miller, Geochemical and Biological Controls over Methylmercury Production and Degradation in Aquatic Ecosystems, Biogeochem. Environ. Important Trace Elem. 835 (2002) 19-262. doi:doi:10.1021/bk-2003-0835.ch019.

[4] C.R. Hammerschmidt, W.F. Fitzgerald, Geochemical Controls on the Production and Distribution of Methylmercury in Near-Shore Marine Sediments, Environ. Sci. Technol. 38 (2004) 1487-1495. doi:10.1021/es034528q.

[5] E.J. Fleming, E.E. Mack, P.G. Green, D.C. Nelson, Mercury Methylation from Unexpected Sources : Molybdate-Inhibited Freshwater Sediments and an Iron-Reducing Bacterium, Appl. Environ. Microbiol. 72 (2006) 457-464. doi:10.1128/AEM.72.1.457.

[6] J.G. Wiener, D.P. Krabbenhoft, G.H. Heinz, M.A. Scheuhammer, Ecotoxicology of mercury. Handbook of Ecotoxicology, Lewis Publisher, 2003.

[7] A. Goutte, P. Bustamante, C. Barbraud, K. Delord, H. Weimerskirch, O. Chastel, Demographic responses to mercury exposure in two closely related antarctic top predators, Ecology. 95 (2014) 1075-1086. doi:10.1890/13-1229.1.

[8] J. Burger, M. Gochfeld, Marine Birds as Sentinels of Environmental Pollution, EcoHealth J. Consort. (2004) 263-274. doi:10.1007/s10393-004-0096-4.

[9] B.M. Braune, Comparison of Total Mercury Levels in Relation to Diet and Molt for Nine Species of Marine Birds, Arch. Environ. Contam. Toxicol. 224 (1987) 217-224.

[10] L.R. Monteiro, V. Costa, R.W. Furness, R.S. Santos, Mercury concentrations in prey fish indicate enhanced bioaccumulation in mesopelagic environments, Mar. Ecol. Prog. Ser. 141 (1996) 21-25. doi:10.3354/meps141021.

[11] K. Honda, T. Nasu, R. Tatsukawa, Seasonal changes in mercury accumulation in the black-eared kite, Milvus migrans lineatus, Environ. Pollut. Ser. A, Ecol. Biol. 42 (1986) 325-334. doi:10.1016/0143-1471(86)90016-4.

[12] R.W. Furness, S.J. Muirhead, M. Woodburn, Using bird feathers to measure mercury in 
the environment: Relationships between mercury content and moult, Mar. Pollut. Bull. 17 (1986) 27-30. doi:10.1016/0025-326X(86)90801-5.

[13] H. Appelquist, S. Asbirk, I.D. Ek, Mercury Monitoring: Mercury Stability in Bird Feathers, 15 (1984) 22-24.

[14] D.. Thompson, S. Bearhop, J.. Speakman, R.. Furness, Feathers as a means of monitoring mercury in seabirds: Insights from stable isotope analysis, Environ. Pollut. 101 (1998) 193-200. doi:10.1016/S0269-7491(98)00078-5.

[15] E. Hahn, K. Hahn, M. Stoeppler, Bird feathers as bioindicators in areas of the German Environmental Specimen Bank - bioaccumulation of mercury in food chains and exogenous deposition of atmospheric pollution with lead and cadmium, Sci. Total Environ. 139/140 (1993) 259-270.

[16] S. Queipo Abad, P. Rodríguez-González, J.I. García Alonso, Evidence of the direct adsorption of mercury in human hair during occupational exposure to mercury vapour, J. Trace Elem. Med. Biol. 36 (2016) 16-21. doi:10.1016/j.jtemb.2016.03.012.

[17] L. Laffont, J.E. Sonke, L. Maurice, S.L. Monrroy, J. Chincheros, D. Amouroux, P. Behra, $\mathrm{Hg}$ speciation and stable isotope signatures in human hair as a tracer for dietary and occupational exposure to mercury, Environ. Sci. Technol. 45 (2011) 9910-9916. doi:10.1021/es202353m.

[18] D.R. Thompson, R.W. Furness, Comparison of the Levels of total and organic mercury in seabird feathers, Mar. Pollut. Bull. 20 (1989) 577-579.

[19] E.Y. Kim, T. Murakami, K. Saeki, R. Tatsukawa, Mercury levels and its chemical form in tissues and organs of seabirds, Arch. Environ. Contam. Toxicol. 30 (1996) 259-266. doi:10.1007/BF00215806.

[20] D.R. Thompson, R.W. Furness, L.R. Monteiro, Seabirds as biomonitors of mercury inputs to epipelagic and mesopelagic marine food chains, Sci. Total Environ. 213 (1998) 299-305. doi:10.1016/S0048-9697(98)00103-X.

[21] A.L. Bond, Æ.A.W. Diamond, Total and Methyl Mercury Concentrations in Seabird Feathers and Eggs, Arch. Environ. Contam. Toxicol. (2009) 286-291. doi:10.1007/s00244-008-9185-7.

[22] D.R. Thompson, R.W. Furness, P.M. Walsh, Historical changes in mercury concentrations in the marine ecosystem of the north and north-east Atlantic ocean as indicated by seabird feathers, J. Appl. Ecol. 29 (1992) 79-84. 
[23] R.W. Furness, D.R. Thompson, P.H. Becker, Spatial and temporal variation in mercury contamination of seabirds in the North Sea, Helgolãnder Meeresuntersuchungen. 49 (1995) 605-615. doi:10.1007/BF02368386.

[24] A.L. Bond, K.A. Hobson, B.A. Branfireun, Rapidly increasing methyl mercury in endangered ivory gull (Pagophila eburnea) feathers over a 130 year record., Proc. R. Soc. B-Biological Sci. 282 (2015) 19-32. doi:10.1098/rspb.2015.0032.

[25] D.R. Thompson, R.W. Furness, S.A. Lewis, Temporal and spatial variation in mercury concentrations in some albatrosses and petrels from the sub-Antarctic, Polar Biol. 13 (1993) 239-244. doi:10.1007/BF00238759.

[26] A.E. Vo, M.S. Bank, J.P. Shine, S. V Edwards, Temporal increase in organic mercury in an endangered pelagic seabird assessed by century-old museum specimens, Proc. Natl. Acad. Sci. U. S. A. (2011). doi:10.1073/pnas.1013865108//DCSupplemental.www.pnas.org/cgi/doi/10.1073/pnas.1013865108.

[27] D. Thompson, R.W. Furness, Differences in the chemical form of mercury stored in South Atlantic seabirds, Environ. Pollut. 60 (1989) 305-317. doi:10.1016/02697491(89)90111-5.

[28] J.S. Uthe, B. Grift, Rapid Semimicro Method for the Determination of Methyl Mercury in Fish Tissue, (1972).

[29] D.R. Thompson, P.H. Becker, R.W. Furness, Long-term changes in mercury concentrations in herring gulls Larus argentatus and common terns Sterna hirundo from the German North Sea coast, J. Appl. Ecol. 30 (1993) 316-320. http://www.scopus.com/inward/record.url?eid=2-s2.0-

0027446064\&partnerID=tZOtx3y1.

[30] L.R. Monteiro, R.W. Furness, Accelerated increase in mercury contamination in North Atlantic mesopelagic food chains as indicated by time series of seabird feathers, Environ. Toxicol. Chem. 16 (1997) 2489-2493. doi:10.1002/etc.5620161208.

[31] M.G. Spalding, P.C. Frederick, H.C. McGill, S.N. Bouton, L.R. McDowell, Methylmercury accumulation in tissues and its effects on growth and appetite in captive great egrets, J. Wildl. Dis. 36 (2000) 411-422. doi:10.7589/0090-3558-36.3.411.

[32] A.L. Bond, A.W. Diamond, Mercury concentrations in seabird tissues from Machias Seal Island, New Brunswick, Canada., Sci. Total Environ. 407 (2009) 4340-7. doi:10.1016/j.scitotenv.2009.04.018.

[33] M.L. Mallory, B.M. Braune, J.F. Provencher, D.B. Callaghan, H.G. Gilchrist, S.T. 
Edmonds, K. Allard, N.J. O’Driscoll, Mercury concentrations in feathers of marine birds in Arctic Canada, Mar. Pollut. Bull. 98 (2015) 308-313. doi:10.1016/j.marpolbul.2015.06.043.

[34] H.A. Kehrig, R.A. Hauser-Davis, T.G. Seixas, G. Fillmann, Trace-elements, methylmercury and metallothionein levels in Magellanic penguin (Spheniscus magellanicus) found stranded on the Southern Brazilian coast, Mar. Pollut. Bull. 96 (2015) 450-455. doi:10.1016/j.marpolbul.2015.05.006.

[35] S. Clémens, M. Monperrus, O.F.X. Donard, D. Amouroux, T. Guérin, Mercury speciation analysis in seafood by species-specific isotope dilution: method validation and occurrence data, Anal Bioanal Chem. 401 (2011) 2699-2711. doi:10.1007/s00216011-5040-1.

[36] P. Rodríguez-González, J.M. Marchante-Gayón, J.I. García Alonso, A. Sanz-Medel, Isotope dilution analysis for elemental speciation: a tutorial review, Spectrochim. Acta Part B At. Spectrosc. 60 (2005) 151-207. doi:10.1016/j.sab.2005.01.005.

[37] S. Clémens, M. Monperrus, O.F.X. Donard, D. Amouroux, T. Guérin, Mercury speciation in seafood using isotope dilution analysis: A review, Talanta. 89 (2012) 1220. doi:10.1016/j.talanta.2011.12.064.

[38] L. Laffont, L. Maurice, D. Amouroux, P. Navarro, M. Monperrus, J.E. Sonke, P. Behra, Mercury speciation analysis in human hair by species-specific isotope-dilution using GC-ICP-MS., Anal. Bioanal. Chem. 405 (2013) 3001-10. doi:10.1007/s00216-0126116-2.

[39] A. Carravieri, P. Bustamante, C. Churlaud, Y. Cherel, Penguins as bioindicators of mercury contamination in the Southern Ocean: birds from the Kerguelen Islands as a case study., Sci. Total Environ. 454-455 (2013) 141-8. doi:10.1016/j.scitotenv.2013.02.060.

[40] US EPA, Mercury total (organic and 7439-97-6 inorganic), Methods. (2007) 1-17.

[41] O.F.X. Tseng, C.M., De Diego, A., Martin, F.M., Amouroux, D., Donard, Rapid determination of inorganic mercury and methylmercury in biological reference materials by hydride generation, cryofocusing, atomic absorption spectrometry after open focused microwave-assisted alkaline digestion, J. Anal. At. Spectrom. 12 (1997) 743-750.

[42] D. Point, J. Ignacio Garcia Alonso, W. Clay Davis, S.J. Christopher, A. Guichard, O.F.X. Donard, P.R. Becker, G.C. Turk, S. a. Wise, Consideration and influence of complexed forms of mercury species on the reactivity patterns determined by speciated 
isotope dilution model approaches: A case for natural biological reference materials, J. Anal. At. Spectrom. 23 (2008) 385. doi:10.1039/b716205g.

[43] M. Monperrus, P.R. Gonzalez, D. Amouroux, J.I.G. Alonso, O.F.X. Donard, Evaluating the potential and limitations of double-spiking species-specific isotope dilution analysis for the accurate quantification of mercury species in different environmental matrices, (2008) 655-666. doi:10.1007/s00216-007-1598-z.

[44] J. Meija, L. Ouerdane, Z. Mester, Isotope scrambling and error magnification in multiple-spiking isotope dilution, Anal. Bioanal. Chem. 394 (2009) 199-205. doi:10.1007/s00216-009-2619-x.

[45] D.R. Thompson, K.C. Hamer, R.W. Furness, Mercury Accumulation in Great Skuas Catharacta Skua of Known Age and Sex, and Its Effects Upon Breeding and Survival, J. Appl. Ecol. 28 (1991) 672-684.

[46] D.. Thompson, S. Bearhop, J.R. Speakmanb, R.W. Furness, Feathers as a means of monitoring mercury in seabirds : insights from stable isotope analysis, Environ. Pollut. 101 (1998) 193-200.

[47] S. Bearhop, G.D. Ruxton, R.W. Furness, Dynamics of mercury in blood and feathers of great skuas, Environ. Toxicol. Chem. 19 (2000) 1638-1643. doi:10.1897/15515028(2000)019<1638:Domiba>2.3.Co;2. 
Table 1. Synthesis of main previous studies on $\mathrm{Hg}$ speciation in feathers in order of publication. Result values are represented as mean \pm SD.

\begin{tabular}{|c|c|c|c|c|c|c|c|c|c|}
\hline Hg speciation approach & Analytical method & Species & Region & $\mathbf{n}$ & THg $\left(\mu \mathrm{g} \cdot \mathrm{g}^{-1}\right)$ & $\mathrm{iHg}\left(\mu \mathrm{g} \cdot \mathrm{g}^{-1}\right)$ & $\operatorname{MeHg}\left(\mu \mathrm{g} \cdot \mathrm{g}^{-1}\right)$ & $\operatorname{MeHg}(\%)$ & Ref \\
\hline \multirow{10}{*}{$\begin{array}{l}\text { Hg species measured: } \\
\text { MeHg, THg }\end{array}$} & \multirow{10}{*}{ CV-AFS } & $\begin{array}{l}\text { Wandering albatross } \\
\text { complex }\end{array}$ & $\begin{array}{l}\text { Gough Island (South Atlantic } \\
\text { Ocean) Marion Island (Indian } \\
\text { Ocean) }\end{array}$ & 26 & $30.7 \pm 11.7$ & $\mathrm{n} / \mathrm{a}$ & $29.2 \pm 11.6$ & 95 & \multirow{10}{*}[18]{} \\
\hline & & Sooty albatross & $\begin{array}{l}\text { Gough Island (South Atlantic } \\
\text { Ocean) }\end{array}$ & 7 & $9.4 \pm 3.9$ & $\mathrm{n} / \mathrm{a}$ & $9.1 \pm 4.0$ & 97 & \\
\hline & & Northern fulmar & Foula (Shetland) & 15 & $1.8 \pm 0.8$ & $\mathrm{n} / \mathrm{a}$ & $2.0 \pm 0.7$ & 111 & \\
\hline & & European shag & Foula (Shetland) & 14 & $1.7 \pm 0.7$ & $\mathrm{n} / \mathrm{a}$ & $2.0 \pm 0.8$ & 118 & \\
\hline & & Great skua & Foula (Shetland) & 14 & $6.8 \pm 4.4$ & $\mathrm{n} / \mathrm{a}$ & $7.3 \pm 5.5$ & 107 & \\
\hline & & Arctic skua & Foula (Shetland) & 9 & $2.2 \pm 1.7$ & $\mathrm{n} / \mathrm{a}$ & $1.7 \pm 1.8$ & 77 & \\
\hline & & Kittiwake & Foula (Shetland) & 14 & $2.4 \pm 0.6$ & $\mathrm{n} / \mathrm{a}$ & $2.2 \pm 0.7$ & 92 & \\
\hline & & Razorbill & Foula (Shetland) & 16 & $2.1 \pm 0.3$ & $\mathrm{n} / \mathrm{a}$ & $2.1 \pm 0.6$ & 100 & \\
\hline & & Common guillemot & Foula (Shetland) & 17 & $1.5 \pm 0.4$ & $\mathrm{n} / \mathrm{a}$ & $1.7 \pm 0.5$ & 113 & \\
\hline & & Puffin & Foula (Shetland) & 10 & $5.2 \pm 2.7$ & $\mathrm{n} / \mathrm{a}$ & $5.1 \pm 2.1$ & 98 & \\
\hline Hg species measured: & \multirow{3}{*}{ CV-AFS } & Oldsquaw & Chaun (Northeast Siberia) & 5 & $0.7 \pm 0.2$ & $\mathrm{n} / \mathrm{a}$ & $0.9 \pm 0.2$ & 128 & \multirow{3}{*}{19} \\
\hline $\mathrm{MeHg}, \mathrm{THg}$ & & Herring gull & Chaun (Northeast Siberia) & 5 & $6.1 \pm 4.6$ & $\mathrm{n} / \mathrm{a}$ & $6.5 \pm 4.5$ & 106 & \\
\hline $\mathrm{MeHg}$ specific extraction & & Arctic tern & Chaun (Northeast Siberia) & 5 & $0.9 \pm 0.1$ & $\mathrm{n} / \mathrm{a}$ & $1.1 \pm 0.1$ & 122 & \\
\hline $\begin{array}{c}\text { Hg species measured: } \\
\text { MeHg, THg } \\
\text { MeHg specific } \\
\text { extraction }\end{array}$ & CV-AFS & Great egret & Everglades (Florida) & 6 & $2.0 \pm 0.2$ & $\mathrm{n} / \mathrm{a}$ & $\mathrm{n} / \mathrm{a}$ & 120 & [31] \\
\hline \multirow{3}{*}{$\begin{array}{c}\text { Hg species measured: } \\
\text { MeHg, THg }\end{array}$} & \multirow{6}{*}{ GC-AFS } & Arctic tern & New Brunswick (Canada) & 5 & $0.9 \pm 0.5$ & $\mathrm{n} / \mathrm{a}$ & $0.8 \pm 0.3$ & $95 \pm 15$ & \multirow{6}{*}{21} \\
\hline & & Common murre & New Brunswick (Canada) & 5 & $1.0 \pm 0.4$ & $\mathrm{n} / \mathrm{a}$ & $1.2 \pm 0.3$ & $133 \pm 33$ & \\
\hline & & Common tern & New Brunswick (Canada) & 5 & $1.4 \pm 0.6$ & $\mathrm{n} / \mathrm{a}$ & $1.6 \pm 1.8$ & $114 \pm 65$ & \\
\hline \multirow[t]{3}{*}{ MeHg specific extraction } & & Razorbill & New Brunswick (Canada) & 5 & $1.8 \pm 0.7$ & $\mathrm{n} / \mathrm{a}$ & $1.1 \pm 0.4$ & $82 \pm 35$ & \\
\hline & & Atlantic puffin & New Brunswick (Canada) & 5 & $4.9 \pm 2.8$ & $\mathrm{n} / \mathrm{a}$ & $1.6 \pm 0.7$ & $100 \pm 50$ & \\
\hline & & Leach's storm petrel & New Brunswick (Canada) & 5 & $4.9 \pm 2.8$ & $\mathrm{n} / \mathrm{a}$ & $5.3 \pm 3.4$ & $99 \pm 40$ & \\
\hline $\begin{array}{c}\text { Hg species measured: } \\
\text { MeHg, iHg,THg } \\
\text { Chromatographic } \\
\text { separation } \\
\end{array}$ & ID-GC-ICPMS & $\begin{array}{l}\text { Black-footed albatross } \\
\text { (post-1990) }\end{array}$ & Pacific Ocean & 10 & $47.9 \pm 35.7$ & $0.5 \pm 1.2$ & $42.1 \pm 30.9$ & $89 \pm 14$ & {$[26]$} \\
\hline $\begin{array}{c}\text { Hg species measured: } \\
\text { MeHg, THg } \\
\text { MeHg specific extraction }\end{array}$ & CV-AFS & $\begin{array}{l}\text { Ivory gulls } \\
\text { (post-1975) }\end{array}$ & Canada & 5 & $3.5 \pm 2.1$ & $\mathrm{n} / \mathrm{a}$ & $2.7 \pm 2.2$ & $68 \pm 37$ & [24] \\
\hline $\begin{array}{c}\text { Hg species measured: } \\
\text { MeHg, THg } \\
\text { Chromatographic } \\
\text { separation }\end{array}$ & GC-ECD & Magellanic penguins & Southern Brazilian coast & 22 & $0.8 \pm 0.4$ & $\mathrm{n} / \mathrm{a}$ & $0.6 \pm 0.3$ & $\mathrm{n} / \mathrm{a}$ & [34] \\
\hline \multirow{6}{*}{$\begin{array}{l}\text { Hg species measured: } \\
\text { MeHg, iHg, THg } \\
\text { Chromatographic } \\
\text { separation }\end{array}$} & & Ivory gulls & Canada & 4 & $11.6 \pm 6.5$ & $\mathrm{n} / \mathrm{a}$ & $9.4 \pm 5.3$ & $81 \pm 4$ & \multirow{6}{*}[33]{} \\
\hline & & Glaucous gull & Canada & 4 & $2.3 \pm 1.7$ & $\mathrm{n} / \mathrm{a}$ & $2.1 \pm 1.7$ & $91 \pm 4$ & \\
\hline & & Black-legged kittiwake & Canada & 2 & $3.6 \pm 0.9$ & $\mathrm{n} / \mathrm{a}$ & $3.3 \pm 0.9$ & $91 \pm n / a$ & \\
\hline & GC-AFS & Common eider & Canada & 10 & $0.6 \pm 0.2$ & $\mathrm{n} / \mathrm{a}$ & $0.5 \pm 0.2$ & $87 \pm 2$ & \\
\hline & & Thick-billed murre & Canada & 10 & $1.9 \pm 0.6$ & $\mathrm{n} / \mathrm{a}$ & $1.7 \pm 0.6$ & $90 \pm 1$ & \\
\hline & & Northern fulmar & Canada & 10 & $2.7 \pm 0.7$ & $\mathrm{n} / \mathrm{a}$ & $2.4 \pm 0.6$ & $88 \pm 1$ & \\
\hline
\end{tabular}


Table 2. Results of $\mathrm{Hg}$ species concentrations and recoveries obtained for the different extraction methods tested in CRM (NIES-13) and calculated by the two different calculation methods (D-IDA and IPD). Species interconversion factors were calculated by IPD. N is referred to number of extractions.

\begin{tabular}{|c|c|c|c|c|c|c|c|c|c|c|c|c|c|c|c|c|c|c|}
\hline \multirow{3}{*}{$\begin{array}{c}\text { NIES-13 } \\
\begin{array}{c}\text { Calculation } \\
\text { method }\end{array} \\
\end{array}$} & \multirow{3}{*}{$\begin{array}{c}\text { Human hair CRM } \\
\text { System }\end{array}$} & \multirow{3}{*}{ Reagent } & \multirow{3}{*}{\begin{tabular}{|c|} 
Spike addition \\
Certified values \\
\end{tabular}} & \multirow{3}{*}{$n$} & \multicolumn{7}{|c|}{ Concentrations $\left(\mathbf{n g} \cdot \mathrm{g}^{-1}\right)$} & \multicolumn{5}{|c|}{ Recoveries (\%) } & \multicolumn{2}{|c|}{ Interconversion factors $(\%)$} \\
\hline & & & & & \multicolumn{2}{|c|}{ MeHg } & \multicolumn{2}{|c|}{ iHg } & \multicolumn{3}{|c|}{ THg } & \multicolumn{2}{|c|}{$\operatorname{MeHg}(\%)$} & \multicolumn{3}{|c|}{$\operatorname{THg}(\%)$} & $\mathbf{M}(\%)$ & $\mathrm{D}(\%)$ \\
\hline & & & & & 3800 & \pm 400 & & & 4420 & \pm & 200 & & & & & & & \\
\hline \multirow{8}{*}{ Single-IDA } & Microwave & $\mathrm{HNO}_{3} \cdot 6 \mathrm{~N}$ & after extraction & 3 & 3064 & \pm 55 & 319 & \pm 148 & 3383 & \pm & 158 & 81 & \pm 1 & 77 & \pm & & & \\
\hline & & & before extraction & 3 & 3647 & \pm 46 & 591 & \pm 53 & 4238 & \pm & 52 & 96.0 & \pm 1.2 & 95.9 & \pm 0 & & & \\
\hline & Microwave & TMAH & after extraction & 3 & 3467 & \pm 236 & 594 & \pm 8 & 4202 & \pm & 104 & 96 & \pm 3 & 95 & \pm & & & \\
\hline & & & before extraction & 3 & 3651 & \pm 417 & 1463 & \pm 398 & 5114 & \pm & 589 & 96 & \pm 11 & 116 & \pm 1 & & & \\
\hline & HotBlock & $\mathrm{HNO} 3 \cdot 6 \mathrm{~N}$ & after extraction & 3 & 3022 & \pm 157 & 661 & \pm 16 & 3683 & \pm & 149 & 80 & \pm 4 & 83 & \pm & & & \\
\hline & & & before extraction & 3 & 3403 & $\pm \quad 28$ & 621 & \pm 64 & 4025 & \pm & 48 & 90 & \pm 1 & 91 & \pm & & & \\
\hline & HotBlock & TMAH & after extraction & 3 & 3364 & \pm 150 & 845 & \pm 99 & 4210 & \pm & 192 & 89 & \pm 4 & 95 & \pm & 4 & & \\
\hline & & & before extraction & 3 & 3549 & \pm 263 & 964 & \pm 257 & 4514 & \pm & 499 & 93 & \pm 7 & 102 & \pm 1 & 11 & & \\
\hline \multirow{8}{*}{ IPD } & Microwave & $\mathrm{HNO}_{3} \cdot 6 \mathrm{~N}$ & after extraction & 3 & 3022 & \pm 18 & 218 & \pm 53 & 3240 & \pm & 62 & 79.5 & \pm 0.5 & 73 & \pm & 1 & $2.8 \pm 1.2$ & $0.3 \pm 0.1$ \\
\hline & & & before extraction & 3 & 3578 & \pm 53 & 565 & \pm 82 & 4143 & \pm & 103 & 94 & \pm 1 & 94 & \pm & 2 & $1.5 \pm 1.2$ & $5.5 \pm 1.0$ \\
\hline & Microwave & TMAH & after extraction & 3 & 3574 & \pm 104 & 616 & \pm 56 & 4191 & \pm & 92 & 96 & \pm 1 & 96 & & 2 & $3.0 \pm 1.5$ & $1.3 \pm 0.6$ \\
\hline & & & before extraction & 3 & 3803 & \pm 112 & 574 & \pm 68 & 4377 & \pm & 44 & 100 & \pm 3 & 99 & \pm & 1 & $1.0 \pm 0.3$ & $26.6 \pm 1.0$ \\
\hline & HotBlock & $\mathrm{HNO} 3 \cdot 6 \mathrm{~N}$ & after extraction & 3 & 2826 & \pm 23 & 704 & \pm 9 & 3529 & \pm & 31 & 74 & \pm 1 & 80 & \pm & 1 & $0.7 \pm 0.2$ & $-1.1 \pm 0.1$ \\
\hline & & & before extraction & 3 & 3421 & $\pm \quad 45$ & 479 & $\pm \quad 22$ & 3900 & \pm & 23 & 90 & \pm 1 & 88 & & 1 & $1.0 \pm 0.3$ & $8.4 \pm 0.1$ \\
\hline & HotBlock & TMAH & after extraction & 3 & 3146 & \pm 186 & 654 & \pm 37 & 3800 & \pm & 148 & 83 & \pm 5 & 86 & \pm & 3 & $1.3 \pm 1.0$ & $2.9 \pm 0.4$ \\
\hline & & & before extraction & 3 & 3346 & $\pm \quad 32$ & 494 & \pm 55 & 3840 & \pm & 87 & 88 & \pm 1 & 87 & \pm & 2 & $2.7 \pm 1.4$ & $7.7 \pm 0.3$ \\
\hline
\end{tabular}


Table 3. Results of $\mathrm{Hg}$ species concentrations and recoveries obtained for the different extraction methods tested in feather internal reference sample (P-KP) and calculated by the two different calculation methods (D-IDA and IPD). Species interconversion factors were calculated by IPD. N is referred to number of extractions.

\begin{tabular}{|c|c|c|c|c|c|c|c|c|c|c|c|c|c|c|c|c|c|c|c|}
\hline \multirow{3}{*}{ Calculation method } & \multicolumn{2}{|c|}{ King penguin feathers (IRM) } & \multirow{3}{*}{$\begin{array}{c}\text { Spike addition } \\
\text { THg AMA-254 (n=12 } \\
\end{array}$} & \multicolumn{10}{|c|}{ Concentrations $\left(n g \cdot g^{-1}\right)$} & \multicolumn{6}{|c|}{ Interconversion factors $(\%)$} \\
\hline & \multirow[t]{2}{*}{ System } & \multirow[t]{2}{*}{ Reagent } & & \multirow[t]{2}{*}{$n$} & \multicolumn{3}{|c|}{ MeHg } & \multicolumn{3}{|c|}{ iHg } & \multicolumn{3}{|c|}{ THg } & \multicolumn{3}{|c|}{$\mathbf{M}(\%)$} & \multicolumn{3}{|c|}{$\mathrm{D}(\%)$} \\
\hline & & & & & & & & & & & 3816 & \pm & 275 & & & & & & \\
\hline \multirow{8}{*}{ Single-IDA } & Microwave & $\mathrm{HNO}_{3} \cdot 6 \mathrm{~N}$ & after extraction & 3 & 2219 & \pm & 50 & 1029 & \pm & 106 & 3249 & \pm & 118 & & & & & & \\
\hline & & & before extraction & 3 & 2539 & \pm & 39 & 1360 & \pm & 49 & 3899 & \pm & 62 & & & & & & \\
\hline & Microwave & TMAH & after extraction & 3 & 2461 & \pm & 159 & 928 & \pm & 83 & 3389 & \pm & 179 & & & & & & \\
\hline & & & before extraction & 3 & 2581 & \pm & 256 & 1592 & \pm & 311 & 4173 & \pm & 237 & & & & & & \\
\hline & HotBlock & $\mathrm{HNO}_{3} \cdot 6 \mathrm{~N}$ & after extraction & 3 & 2238 & \pm & 40 & 1267 & \pm & 77 & 3506 & \pm & 87 & & & & & & \\
\hline & & & before extraction & 3 & 2376 & \pm & 22 & 1315 & \pm & 13 & 3691 & \pm & 28 & & & & & & \\
\hline & HotBlock & TMAH & after extraction & 3 & 2733 & \pm & 70 & 1003 & \pm & 50 & 3737 & \pm & 86 & & & & & & \\
\hline & & & before extraction & 3 & 2384 & \pm & 192 & 1438 & \pm & 137 & 3822 & \pm & 225 & & & & & & \\
\hline \multirow{8}{*}{ IPD } & Microwave & $\mathrm{HNO}_{3} \cdot 6 \mathrm{~N}$ & after extraction & 3 & 2175 & \pm & 43 & 1162 & \pm & 991 & 3337 & \pm & 101 & 1.3 & \pm & 1.1 & 0.5 & \pm & 0.7 \\
\hline & & & before extraction & 3 & 2585 & \pm & 22 & 1405 & \pm & 46 & 3990 & \pm & 51 & 0.3 & \pm & 0.3 & 4.5 & \pm & 0.2 \\
\hline & Microwave & TMAH & after extraction & 3 & 2161 & \pm & 23 & 964 & \pm & 67 & 3125 & \pm & 71 & 8.8 & \pm & 1.9 & 0.2 & \pm & 0.3 \\
\hline & & & before extraction & 3 & 2505 & \pm & 284 & 1217 & \pm & 114 & 3722 & \pm & 323 & 0.1 & \pm & 0.8 & 11.3 & \pm & 10.4 \\
\hline & HotBlock & $\mathrm{HNO}_{3} \cdot 6 \mathrm{~N}$ & after extraction & 3 & 2165 & \pm & 106 & 1240 & \pm & 77 & 3404 & \pm & 131 & 2.8 & \pm & 1.5 & 0.2 & \pm & 0.2 \\
\hline & & & before extraction & 3 & 2374 & \pm & 24 & 1194 & \pm & 24.4 & 3568 & \pm & 40 & 0.5 & \pm & 0.2 & 3.3 & \pm & 0.8 \\
\hline & HotBlock & TMAH & after extraction & 3 & 2118 & \pm & 138 & 1110 & \pm & 47 & 3228 & \pm & 145 & 11.9 & \pm & 8.6 & 1.0 & \pm & 0.9 \\
\hline & & & before extraction & 3 & 2452 & \pm & 156 & 1266 & \pm & 90.9 & 3718 & \pm & 184 & 1.4 & \pm & 1.3 & 6.5 & \pm & 1.5 \\
\hline
\end{tabular}


Table 4. Results of MeHg, iHg and THg concentrations obtained for feathers of 13 seabird species of the Southern Ocean. Values are expressed as mean \pm SD. N means number of individuals analysed. Groups with different letter presented statistically different values (Kruskal-Wallis).

\begin{tabular}{|c|c|c|c|c|c|c|c|c|c|c|c|c|c|}
\hline \multirow[t]{2}{*}{ Species } & \multirow[t]{2}{*}{ Locality } & \multirow{2}{*}{$\begin{array}{l}\text { Sampling } \\
\text { dates }\end{array}$} & \multirow[t]{2}{*}{ Status } & \multirow[t]{2}{*}{ Chick diet } & \multirow[t]{2}{*}{$\mathbf{n}$} & \multirow{2}{*}{\multicolumn{2}{|c|}{$\begin{array}{c}\text { THg } \\
\left(\mathrm{ng} \mathrm{g}^{-1}\right) \\
\end{array}$}} & \multirow{3}{*}{$\begin{array}{c}\text { iHg } \\
\left(\mathbf{n g ~ g}^{-1}\right)\end{array}$} & \multicolumn{5}{|c|}{ MeHg } \\
\hline & & & & & & & & & $\left(\operatorname{ng~g}^{-1}\right)$ & Statistic & $\%$ & & Statistic \\
\hline Emperor penguin & Terre Adélie & Nov 2011 & Chicks & pelagic fish & 10 & $812 \pm 100$ & $(662-1047)$ & & $764 \pm 96$ & A,B & $94 \pm 2$ & $(88-97 \%)$ & B,C.D.E \\
\hline King penguin & Crozet & Oct 2011 & Adults & pelagic fish & 11 & $2291 \pm 704$ & $(1658-4141)$ & $178 \pm 82$ & $2113 \pm 633$ & $\mathrm{D}, \mathrm{E}, \mathrm{F}$ & $92 \pm 2$ & $(89-95 \%)$ & $\mathrm{A}, \mathrm{B}, \mathrm{C}, \mathrm{D}$ \\
\hline Adélie penguin & Terre Adélie & Feb 2012 & Adults & $\begin{array}{c}\text { pelagic } \\
\text { crustaceans \& } \\
\text { fish }\end{array}$ & 10 & $375 \pm 87$ & $(289-532)$ & $28 \pm 16$ & $347 \pm 76$ & A & $93 \pm 3$ & $(88-98 \%)$ & $\mathrm{A}, \mathrm{B}, \mathrm{C}, \mathrm{D}, \mathrm{E}$ \\
\hline Gentoo penguin & Crozet & Oct 2011 & Adults & $\begin{array}{l}\text { crustaceans \& } \\
\text { fish }\end{array}$ & 11 & $4330 \pm 1853$ & $(1548-7590)$ & $430 \pm 181$ & $3899 \pm 1686$ & $\mathrm{E}, \mathrm{F}$ & $90 \pm 2$ & $(87-92 \%)$ & A \\
\hline Macaroni penguin & Crozet & Jan 2012 & Adults & $\begin{array}{c}\text { pelagic } \\
\text { crustaceans \& } \\
\text { fish }\end{array}$ & 10 & $2274 \pm 244$ & $(1852-2575)$ & $222 \pm 49$ & $2053 \pm 231$ & $\mathrm{~F}, \mathrm{G}$ & $90 \pm 2$ & $(87-94 \%)$ & A \\
\hline $\begin{array}{l}\text { Southern rockhopper } \\
\text { penguin }\end{array}$ & Crozet & Feb 2012 & Adults & $\begin{array}{c}\text { pelagic } \\
\text { crustaceans \& } \\
\text { fish }\end{array}$ & 10 & $1388 \pm 243$ & $(1055-1685)$ & $110 \pm 36$ & $1279 \pm 214$ & $\mathrm{~A}, \mathrm{~B}, \mathrm{C}$ & $92 \pm 2$ & $(90-95 \%)$ & $\mathrm{A}, \mathrm{B}, \mathrm{C}$ \\
\hline $\begin{array}{l}\text { Northern rockhopper } \\
\text { penguin }\end{array}$ & Amsterdam & Nov 2011 & Adults & $\begin{array}{c}\text { pelagic } \\
\text { crustaceans, } \\
\text { fish \& squid }\end{array}$ & 10 & $1692 \pm 241$ & $(1250-2033)$ & $122 \pm 43$ & $1571 \pm 243$ & $\mathrm{~B}, \mathrm{C}, \mathrm{D}$ & $93 \pm 3$ & $(88-95 \%)$ & $\mathrm{A}, \mathrm{B}, \mathrm{C}, \mathrm{D}, \mathrm{E}$ \\
\hline \multicolumn{14}{|l|}{ Diomedeidae } \\
\hline Wandering albatross & Crozet & $\begin{array}{l}\text { Dec 2007- } \\
\text { Mar } 2008\end{array}$ & Adults & cephalopods & 10 & $39924 \pm 29412$ & $(6334-91651)$ & $3044 \pm 2846$ & $35880 \pm 28229$ & $\mathrm{~J}$ & $90 \pm 6$ & $(81-99 \%)$ & $\mathrm{A}, \mathrm{B}, \mathrm{C}$ \\
\hline \multicolumn{14}{|l|}{ Procellariidae } \\
\hline Northern giant petrel & Crozet & Jan 2009 & Chicks & seabirds & 10 & $5760 \pm 1675$ & $(3935-8867)$ & $447 \pm 145$ & $5317 \pm 1543$ & $\mathrm{G}, \mathrm{H}$ & $92 \pm 1$ & $(90-94 \%)$ & $\mathrm{A}, \mathrm{B}, \mathrm{C}$ \\
\hline Northern giant petrel & Crozet & Nov 2008 & Adults & seabirds & 10 & $12714 \pm 6904$ & $(4730-28823)$ & $541 \pm 364$ & $12173 \pm 6563$ & $\mathrm{I}, \mathrm{J}$ & $96 \pm 1$ & $(90-94 \%)$ & $\mathrm{E}$ \\
\hline Southern giant petrel & Crozet & $\begin{array}{l}\text { Feb-Mar } \\
2009\end{array}$ & Chicks & seabirds & 11 & $5795 \pm 821$ & (4899-7733) & $532 \pm 146$ & $5263 \pm 829$ & $\mathrm{G}, \mathrm{H}$ & $91 \pm 3$ & $(84-93 \%)$ & A,B \\
\hline Southern giant petrel & Crozet & Oct 2009 & Adults & seabirds & 10 & $11082 \pm 4623$ & (5066-19966) & $587 \pm 301$ & $10495 \pm 4438$ & $\mathrm{I}, \mathrm{J}$ & $95 \pm 2$ & $(89-96 \%)$ & $\mathrm{C}, \mathrm{D}, \mathrm{E}$ \\
\hline Antarctic prion & Kerguelen & Jan 2012 & Adults & crustaceans & 10 & $2568 \pm 918$ & (1219-3985) & $152 \pm 68$ & $2416 \pm 888$ & $\mathrm{D}, \mathrm{E}, \mathrm{F}$ & $92 \pm 1$ & $(89-94 \%)$ & $\mathrm{A}, \mathrm{B}, \mathrm{C}$ \\
\hline \multicolumn{14}{|l|}{ Stercorariidae } \\
\hline Antarctic skua & Terre Adélie & $\begin{array}{l}\text { Dec 2011- } \\
\text { Jan } 2012\end{array}$ & Chicks & penguins & 11 & $1933 \pm 284$ & $(1338-2393)$ & $165 \pm 80$ & $1817 \pm 266$ & $\mathrm{C}, \mathrm{D}, \mathrm{E}$ & $92 \pm 3$ & $(84-95 \%)$ & $\mathrm{A}, \mathrm{B}, \mathrm{C}$ \\
\hline Subantarctic skua & Kerguelen & Dec 2011 & Chicks & petrels & 10 & $6978 \pm 116$ & (4134-8210) & $500 \pm 189$ & $6493 \pm 1082$ & $\mathrm{H}, \mathrm{I}$ & $93 \pm 2$ & $(89-96 \%)$ & $\mathrm{A}, \mathrm{B}, \mathrm{C}, \mathrm{D}, \mathrm{E}$ \\
\hline Subantarctic skua & Crozet & $\begin{array}{c}\text { Jan-Feb } \\
2012\end{array}$ & Chicks & $\begin{array}{l}\text { penguins \& } \\
\text { rats }\end{array}$ & 11 & $4911 \pm 162$ & (2293-6328) & $273 \pm 173$ & $4642 \pm 1507$ & $\mathrm{G}, \mathrm{H}$ & $95 \pm 2$ & $(89-97 \%)$ & $\mathrm{C}, \mathrm{D}, \mathrm{E}$ \\
\hline Subantarctic skua & Amsterdam & Dec 2011 & Chicks & $\begin{array}{l}\text { unknown } \\
\text { (seabirds?) }\end{array}$ & 10 & $12366 \pm 2443$ & $(9271-17667)$ & $584 \pm 130$ & $11782 \pm 2376$ & $\mathrm{I}, \mathrm{J}$ & $95 \pm 1$ & $(94-96 \%)$ & $\mathrm{D}, \mathrm{E}$ \\
\hline
\end{tabular}


Figure 1: Optimisation procedure for $\mathrm{Hg}$ speciation analyses in feathers: scheme of the extraction methods tested

1) Sample amount

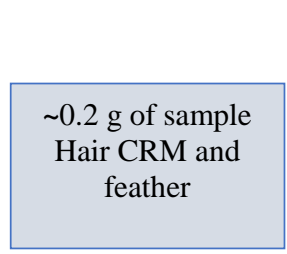

2) Reactant

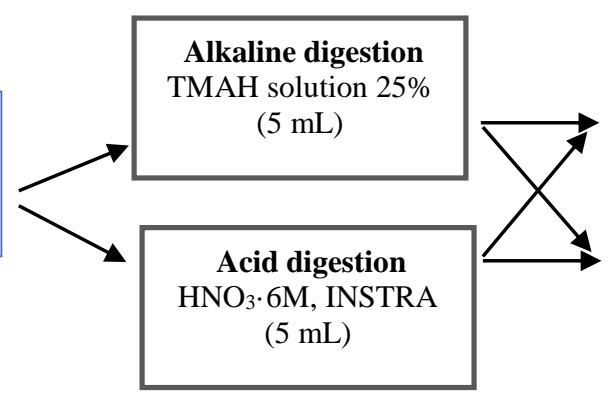

3) Extraction system

Microwave

Ambient Temp $\rightarrow 75^{\circ} \mathrm{C}$

$1 \mathrm{~min} 3 \mathrm{~min}$

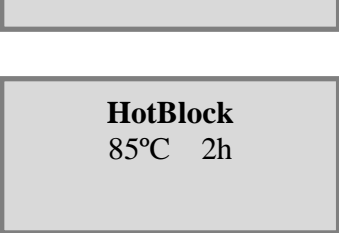

4) Addition of isotopically enriched solutions

Before extraction

After extraction 
Figure 2: Sample preparation flow chart of the two methods compared: speciation extraction and $\mathrm{MeHg}$ specific extraction in human hair and feather samples.

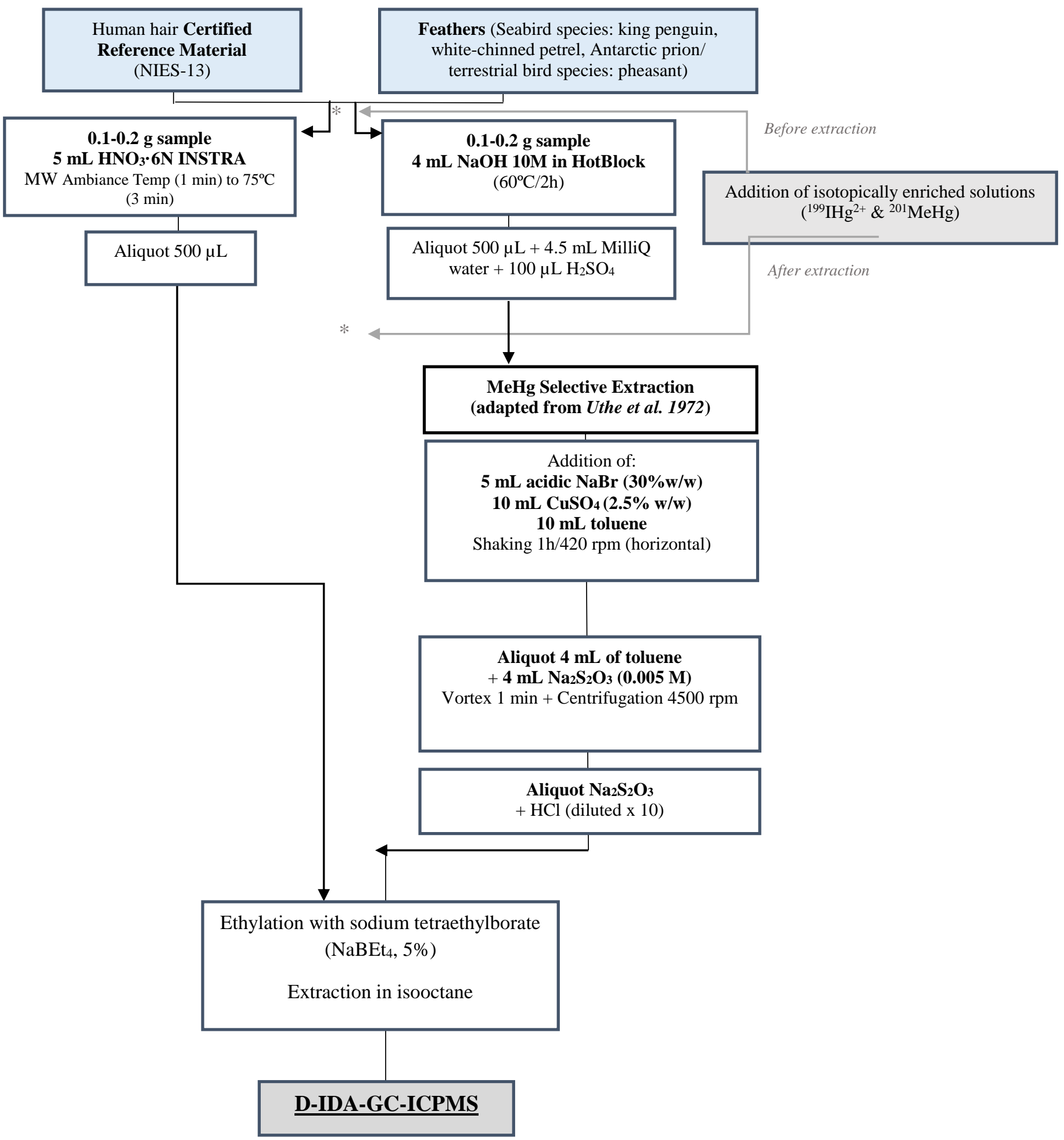


Figure 3: Comparison of $\mathrm{MeHg}$ concentrations (ng. $\mathrm{g}^{-1}$, logarithmic representation) obtained by simultaneous species extraction (SSE) and MeHg selective extraction (MSE) methods by isotope dilution analyses with spike addition before extraction in certified reference material (NIES-13) and feather samples for the key species studied. Trend line $y=1.0399 x-0.0798$ (Pearson's correlation, $\mathrm{r}=0.998, \mathrm{p}<0.001, \mathrm{n}=5$ )

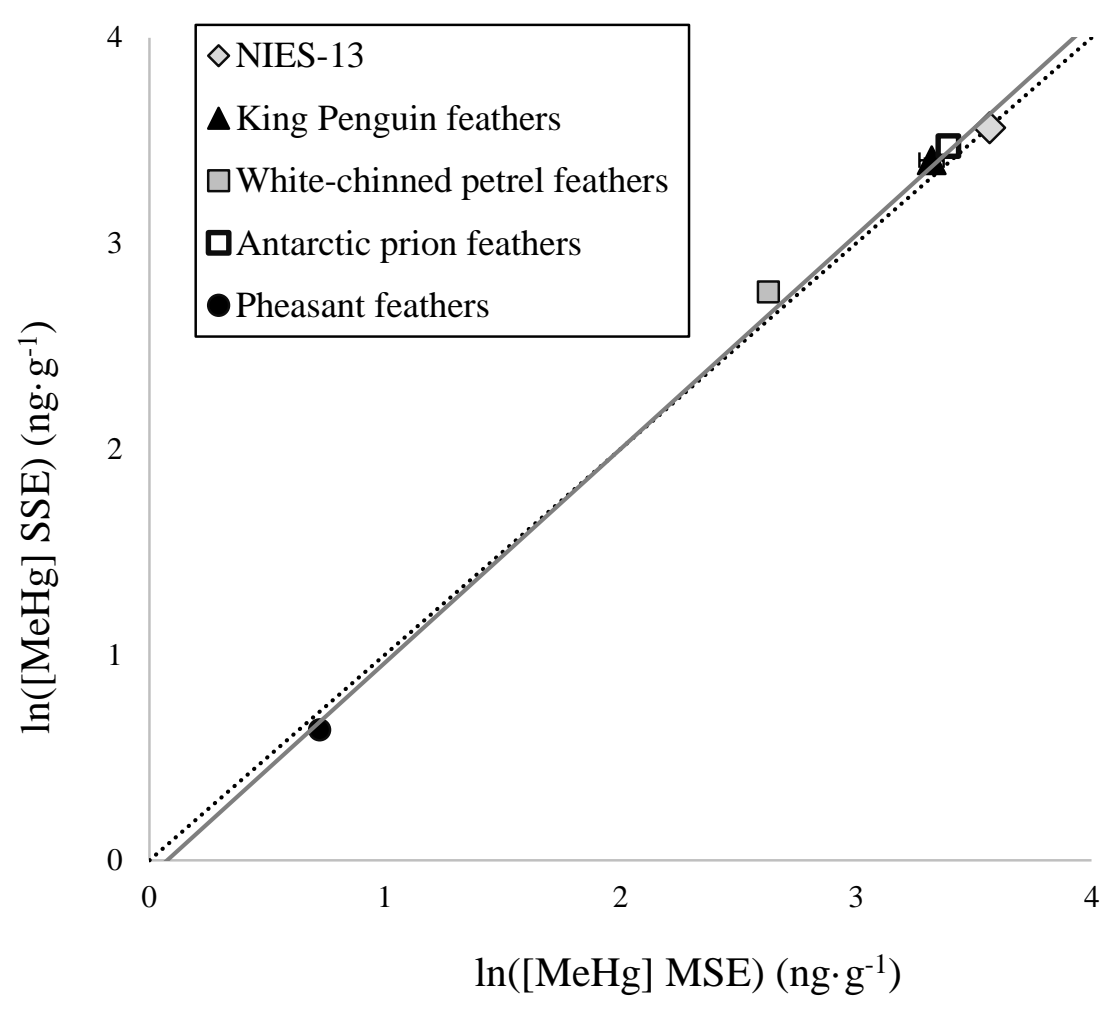




\section{Supplementary material}

\section{Assessment of mercury speciation in feathers using species-specific isotope dilution analysis}

$\underline{\text { Marina Renedo }}^{1,2}$, Paco Bustamante ${ }^{1}$, Emmanuel Tessier ${ }^{2}$, Zoyne Pedrero ${ }^{2}$, Yves Cherel $^{3}$, David Amouroux $^{2}$

${ }^{1}$ Littoral Environnement et Sociétés (LIENSs), UMR 7266 CNRS-Université de la Rochelle, 2 rue Olympe de Gouges, 17000 La Rochelle, France

${ }^{2}$ Institut des sciences analytiques et de physico-chimie pour l'environnement et les matériaux, CNRS-UPPA-UMR-5254, Hélioparc, 2 Avenue du Président Pierre Angot, Pau, 64053, France

${ }^{3}$ Centre d'Etudes Biologiques de Chizé (CEBC), UMR 7372 CNRS-Université de La Rochelle, 79360 Villiers-en-Bois, France

Content:

- 3 tables

- 2 figures 
Table S1. Comparison of analytical performances for acid and alkaline reagents by using microwave assisted extraction (3 extractions) of both studied matrixes human hair CRM (NIES-13) and feathers IRM (P-KP).

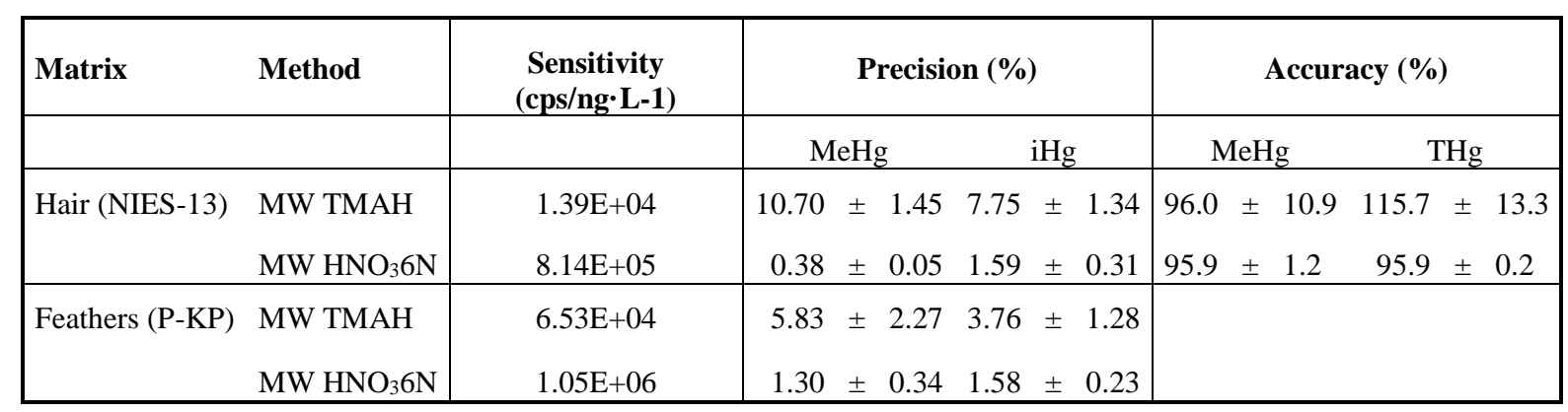


Table S2. Comparison of THg concentrations obtained by the developed speciation method (SSE) and AMA-254 analyses in feather samples. $\mathrm{N}$ for SSE method is referred to number of extractions (analysed in triplicate). $\mathrm{N}$ for AMA-254 is referred to number of analyses.

\begin{tabular}{|c|c|c|c|c|c|c|c|c|c|}
\hline \multirow[t]{2}{*}{ Sample } & \multicolumn{4}{|c|}{ THg SSE $\left(\mathrm{ng} \mathrm{g}^{-1}\right)$} & \multicolumn{4}{|c|}{ THg AMA-254 $\left(\right.$ ng g $\left.^{-1}\right)$} & \multirow{2}{*}{$\begin{array}{c}\operatorname{Rec}(\%) \text { as } \\
(\text { AMA-254/SSE)*100 }\end{array}$} \\
\hline & Mean & SD & RSD & $\%)$ & Mean & SD & $\operatorname{RSD}(\%)$ & & \\
\hline P-KP & 3899 & 62 & 1.6 & $(n=3$ ext $)$ & 3816 & 275 & 7.2 & $(n=12)$ & 98 \\
\hline P-WCP02 & 724 & 6 & 0.8 & $(n=3$ ext $)$ & 706 & 33 & 4.7 & $(n=3)$ & 98 \\
\hline P-FA09 & 3711 & 12 & 0.3 & $(n=3$ ext $)$ & 3589 & 155 & 4.3 & $(n=3)$ & 97 \\
\hline
\end{tabular}


Table S3: Comparison of MeHg concentrations obtained for simultaneous species extraction (SSE) and $\mathrm{MeHg}$ selective extraction (MSE) methods by isotope dilution analyses with spike addition before extraction in Certified Reference Materials (NIES-13) and feather samples for the key species studied. $\mathrm{N}$ is referred to number of extractions

\begin{tabular}{|c|c|c|c|c|c|c|c|c|c|}
\hline \multicolumn{3}{|c|}{ Sample } & \multicolumn{2}{|l|}{$n$} & \multicolumn{2}{|c|}{$\begin{array}{r}\text { MeHg } \\
\left(n g \cdot g^{-1}\right)\end{array}$} & \multicolumn{3}{|c|}{$\begin{array}{l}\text { Recovery (\%) } \\
\text { MSE/SSE*100 }\end{array}$} \\
\hline \multirow[t]{4}{*}{ NIES-13 } & Human hair CRM & Certified values & & 3800 & \pm & 400 & & & \\
\hline & & SSE & 3 & 3647 & \pm & 46 & 96 & \pm & 3 \\
\hline & & MSE spike after & 3 & 3045 & \pm & 142 & 80 & \pm & 4 \\
\hline & & MSE spike before & 3 & 3687 & \pm & 233 & 97 & \pm & 6 \\
\hline \multirow[t]{3}{*}{$\mathrm{P}-\mathrm{KP}$} & King penguin feathers & SSE & 3 & 2539 & \pm & 39 & & & \\
\hline & & MSE spike after & 3 & 1971 & \pm & 9 & 76 & \pm & 7 \\
\hline & & MSE spike before & 3 & 2108 & \pm & 260 & 82 & \pm & 10 \\
\hline \multirow[t]{3}{*}{ P-WCP02 } & White-chinned petrel feathers & SSE & 1 & 579 & \pm & 7 & & & \\
\hline & & MSE spike after & & NA & & & & & \\
\hline & & MSE spike before & 1 & 425 & \pm & 17 & 73 & \pm & 3 \\
\hline \multirow[t]{3}{*}{ P-FA09 } & Antarctic prion feathers & SSE & 1 & 2966 & \pm & 8 & & & \\
\hline & & MSE spike after & 1 & 1883 & & 35 & 63 & \pm & 1 \\
\hline & & MSE spike before & 1 & 2472 & \pm & 64 & 83 & \pm & 2 \\
\hline \multirow[t]{3}{*}{ P-FSN } & Pheasant feathers & SSE & 1 & 4.3 & \pm & 0.1 & & & \\
\hline & & MSE spike after & 1 & 4.3 & \pm & 0.2 & 100 & \pm & 4 \\
\hline & & MSE spike before & 1 & 5.3 & \pm & 0.1 & 123 & \pm & 3 \\
\hline
\end{tabular}


Figure S1: Control charts of measured MeHg and THg concentrations for reference materials NIES-13 and P-KP for each analytical session.
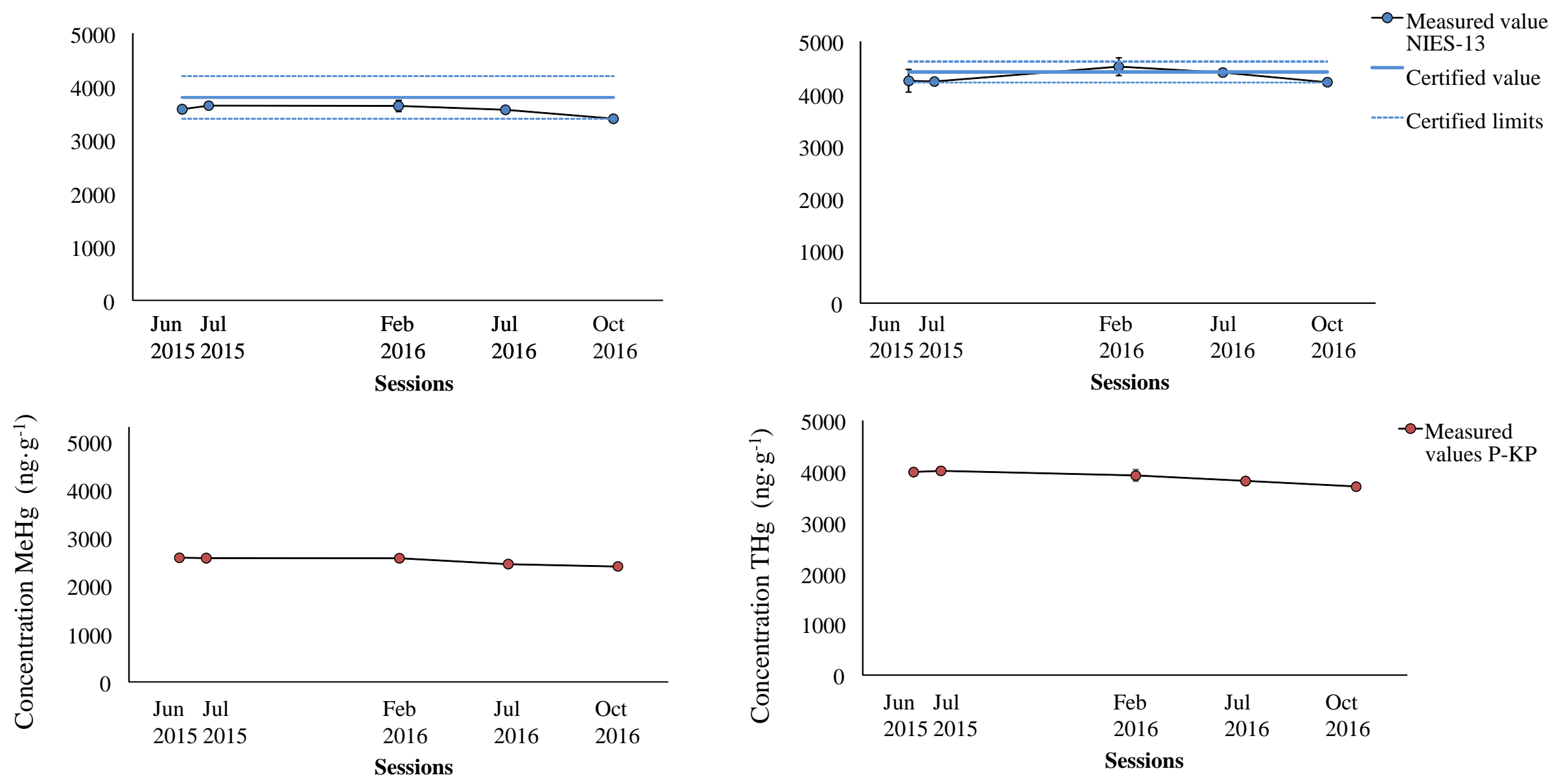

Measured values P-KP 
Figure S2. Comparison of $\mathrm{THg}$ concentrations (ng. $\mathrm{g}^{-1}$, logarithmic representation) obtained by simultaneous species extraction SSE (MeHg+iHg) and by AMA-254 for all feather samples of the 13 seabird species studied ( $\mathrm{n}=175$ individuals).

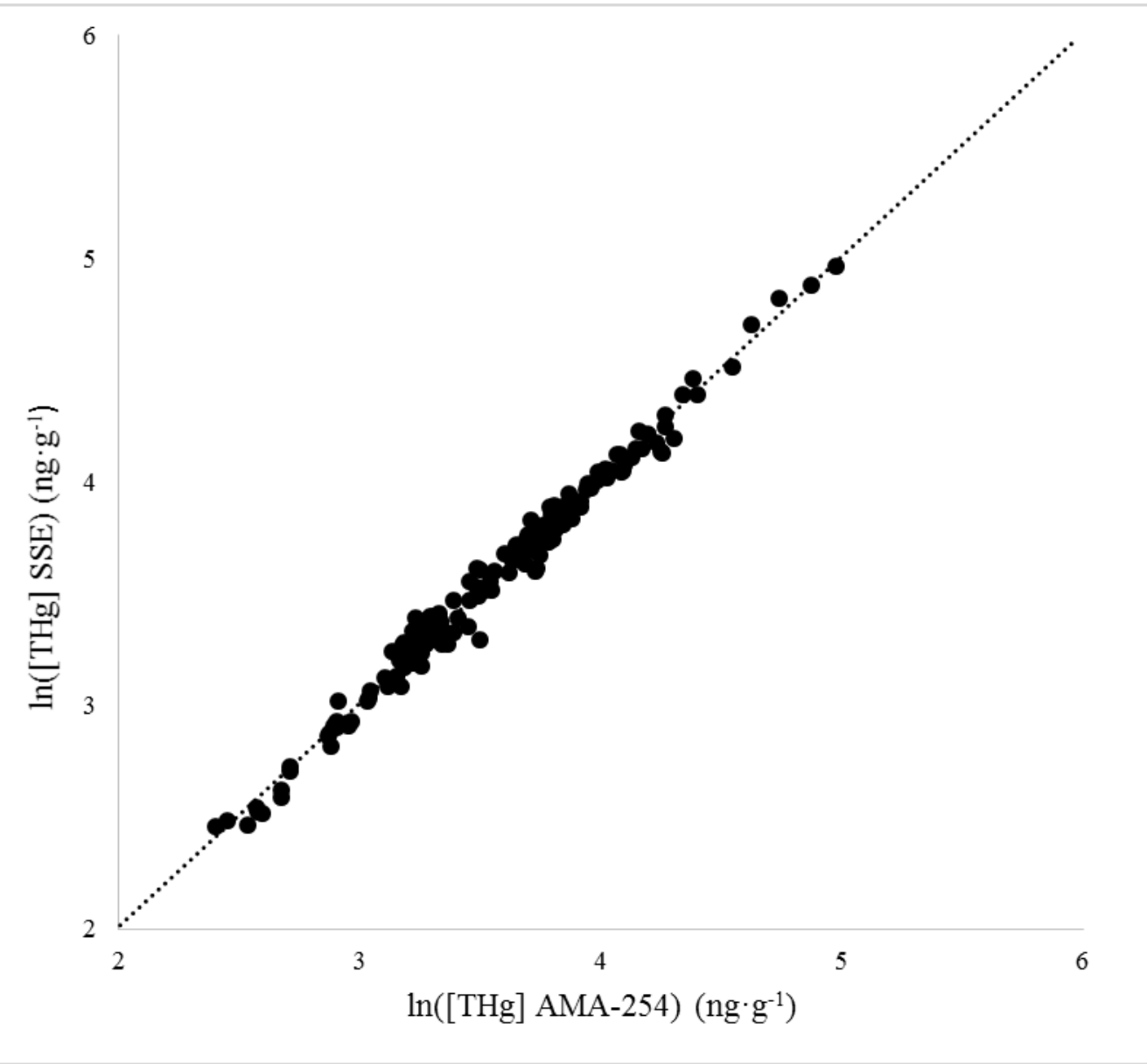

